\title{
İslam Dininde Tevhid-Özgürlük İlişkisi
}

\begin{abstract}
Öz: İslam, Yüce Allah'in insanlığa gönderdiği son ilahi dindir. İslam’a göre varlık, zorunlu ve mümkün olmak üzere ikiye ayrılmaktadır. Zorunlu varlık, bir ve tek, mümküne bağlı olmayan, irade ve kudreti sonsuz olan Yüce Yaratıcı'dır. O'nun dışındaki diğer şeyler ise mümkün varlık olarak kabul edilmektedir. Mümkünün, kendi başına var olması ve varlığı$\mathrm{n} ı$ devam ettirmesi söz konusu değildir. Aksine varlığı, tamamen zorunlu varlığa bağlıdır. $\mathrm{Bu}$ varlık kategorisinde irade ve seçim sahibi olan somut yegâne varlık insandır. Gerçek anlamda sadece insanın irade ve tercihi, özgürlük ve sorumluluğu vardır. Bu bağlamda insanın, Yüce Yaratıcı'yla, kendisiyle ve diğer varlıklarla bilinçli bir etkileşimi söz konusudur. Bu etkileşim, bizzat kendi hür iradesiyle gerçekleşir ki, buna da "insan özgürlüğü" denir. Özgürlük tanımına gelince, insan iradesinin ne kendisi ne de herhangi bir kişi veya durum tarafından engellenmemesi ya da herhangi bir davranışa zorlanmamasıdır. Diğer bir ifadeyle özgürlük, kişinin, kendi inanç, fikir ve davranışlarını herhangi bir baskı ve engel olmadan belirleyebilmesidir. Özgürlük, öncelikle Allah’tan başkasına kul olmamak ve nihayetinde içgüdü ve tutkularının güdümünden kurtulmak demektir. Fakat böyle bir durum, insanın kendi Yaratıcı'sına karşı istediği gibi davranma iznini vermemektedir. Özgürlük denilince ilk olarak insanın, Allah'a karşı görev ve sorumlulukları, daha sonra kendine ve nihayet diğer varlıklara karşı tutum ve davranışları akla gelir. Zira insanın, başta Yüce Yaratıcı'ya, sonra kendine ve daha sonra ise var olan bütün unsurlara karşı sorumluluğu söz konusudur. Bu yüzden o, nefsini ve tabiatı istediği gibi kullanıp tahrip ederek değil, ancak onları koruyup geliştirerek kullanabilir. Sonuç olarak denilebilir ki, insan, mutlak özgür olan Allah'a nispet edince cebir altında, mutlak cebir altında olan diğer mümkün varlıklara göre ise özgürdür..
\end{abstract}

Anahtar Kelimeler: İslam, Din, Tevhid, Ahlak, Özgürlük.

\section{Maksut ÇETIN}

\section{The Relationship of Freedom-Tawhid in Islamic Religion}

Abstract: Islam is the last divine religion that Almighty God sent to humanity. According to Islam, existence is divided into two as compulsory and possible. The necessary being is the Supreme Creator, the one and only, not dependent on the contingent and whose will and power is infinite. Other things other than Him are accepted as possible entities. It is not possible for the possible to exist and survive on its own. Rather, its existence depends entirely on the Necessary being. Among these beings, the only tangible being that has will and choice is human. That is, human being is the only creature who has will and choice, freedom and responsibility exactly. In this respect, there is a conscious interaction with the Supreme Creator and other beings. This interaction takes place by his own free will, which is called "human freedom". When it comes to definition of the freedom, it is neither being obstructed by himself, a person or thing nor being forced to act. In other words, freedom is the determination of one's own beliefs, ideas and behaviors without any pressure or obstacle. Therefore, freedom means first of all not being a servant to anyone other than God, and ultimately freed from the motivation of his instincts and passions. However, this does not allow him to act as he wishes towards his Creator. Therefore, when it comes to freedom, the first thing that comes to mind is the human's duties and responsibilities towards God, then his attitude and behavior towards himself and other beings. That is, he has a responsibility, first to the Supreme Creator, then to himself, and then to all elements in nature. Thus, he can't use his ego as he wishes and cannot destroying nature. He can utilize them provident that he protects and improves them. In conclusion, it can be said that while human beings are under compulsion relative to Allah, who is the absolute free being, he is a free being compared to other possible beings who are under absolute force.

Keywords: Islam, Religion, Tawhid, Ethics, Freedom. 


\section{Giriş}

Tevhid, sözlükte bir ve tek olmak anlamındaki "v-h-d" kökünden türemiş olup bir şeyin bir ve tek olduğunu kabul etmek demektir. Terim olarak ise, Yüce Allah'ın varlığına ve birliğine inanmak anlamına gelir'. İslam dininde tevhid inancı ve insan özgürlüğü arasındaki ilişkiyi anlayabilmek için öncelikle insanın ontolojik konumunu tespit etmek gerekir. Diğer bir ifadeyle, insanın, Allah karşısındaki konumu, varlık hiyerarşisindeki yeri, görev ve sorumlulukları belirlenmeden özgürlük kavramını izah etmek mümkün değildir. Zira özgürlük denilince akla ilk olarak insanın Allah'a karşı görev ve sorumlulukları, daha sonra kendine ve diğer varlıklara karşı tutum ve davranışları gelir.

Tarih boyunca, insan bilincinden bağımsız olsun veya olmasın varlık kavramı, var olan her şeyin ortak adı olarak kullanıla gelmiştir. Esasında varlık, var olanların ortak bir sıfatıdı². Varlığı bir bütün olarak ele alan ontoloji (varlıkbilim), onu somut, soyut ve zihinsel olmak üzere üç temel kategoride ele almış ve dolayısıyla varlığın, bu düzlemlere ait bilgi kaynakları, ifade tarzları, kelime ve kavramları da birbirinden farklı olmuştur ${ }^{3}$. Bu sebeple özgürlük ilkesinin, aşkın, manevi ve Yüce Yaratıc ve somut, maddi ve fiziki bir varlık olan insan için ifade ettiği anlamın birbirinden farklı olması kaçınılmazdır.

İslami ilimlerde varlık, genel olarak iki kısımda ele alınmıştır. Bunlardan biri Vacip (zorunlu, mutlak), diğer(ler)i ise mümkün varlık(lar)dır. Zorunlu varlık, zaman ve mekân dışı, değişmeyen, yok olmayan, sabit, varlığı kendinden olan, var olmak için başkasına muhtaç olmayan, ezelî, ebedîdir. Bu varlık, diğer varlıkların var olma ve varlığını devam ettirme nedeni, yani tüm hayat ve varlığın gerçek var olma illeti ve birlik sebebi olduğundan O'nun ilim, irade ve kudretinde her hangi bir sınırlama söz konusu olamaz . Bundan dolayı Kur'an-ı Kerim'de, O'nun bilgisi sonsuz ${ }^{5}$, iradesi engelsiz ${ }^{6}$, kudreti ise sınırsız ${ }^{7}$ ifade edilerek özgürlüğü tartışmasız kılınmıştır ${ }^{8}$.

1 Ali b. Muhammed eş-Şerif el-Cürcanî, , et-Ta'rifat, thk. Muhammed Sıddîk el-Minşavî, (Kahire 2004), 62; Mevlüt Özler, "Tevhid", İslam Ansiklopedisi, XXXXI, 1147. Şaban Ali Düzgün, "Varlık”, Kelam El Kitabı, (Ankara: Grafiker Yayınları, 2015), 203.

4 Nûreddin es-Sabunî, Mâturidiyye Akaidi, trc. Bekir Topaloğlu, (İstanbul: M. Ü. İlahiyat Fakültesi Vakfı Yayınları, 2011), 58.

5 En'am, 6/59.

6 Yasin, 36/82.

7 Lokman, 31/28.

8 Enbiya, 21/23. 
Mümkün varlık(lar) ise zaman ve mekâna bağlı olan, değişen, hem varlığı hem de yokluğu ihtimal dahilinde olan varlıklardır. Bu varlık çeşidi, Vacip varlığın yaratığı fiziksel, biyolojik ve toplumsal kanunlar çerçevesinde var olur ve yaşamını sürdürür. Bu varlık, Mutlak varlığın isim ve sıfatlarının tecellisi olarak ortaya çıkar. Bu nedenle, onlardaki çokluk, bir varlığın muhtelif aynalardaki yansıması gibi, varlıkta değil, surette gerçekleşen izafi bir çokluktur. Zira bu tür varlıklar, zorunlu varlığa nispeten izafî, vehmî, itibarî ya da gölge varlıklar olarak isimlendirilmiştir.

Mümkün varlıklar içinde, özel bir yere sahip olan ve kendisine özgü bir yaşam hakkı sunulan yegane varlık insanoğludur. İslam dinine göre o, mümkünler içerisinde şerefli kılınan ${ }^{10}$, en güzel şekilde yaratılan ${ }^{11}$, halife tayin edilerek sorumluluk yüklenen ${ }^{12}$ ve Vacip varlığın kendi ruhundan bir parça üflediği ${ }^{13}$ biricik varlıktır. Onun için insan, Mutlak varlık olan Allah'ın isim ve sıfatlarını tezahür ettiren bir ayna olarak telakki edilmiştir. Bu yüzden, İslam'a göre o, ne Yüce Yaratıcı ile eşdeğer ne de diğer varlıklar gibi sıradan kabul edilmiştir. Başka bir ifadeyle insan, mutlak özgürlük sahibi olan Allah'a nispeten cebir altında, mutlak cebir altında olan diğer varlıklara göre ise özgür bir varlık olarak kabul edilmiştir. Sonuç olarak insan, irade ve tercihi, özgürlük ve sorumluluğu olan bir varlık olarak telakki edilmiştir ${ }^{14}$.

Ontolojik olarak insanoğlunun, hem Yüce Yaratıcı'yla hem kendisiyle hem de diğer varlıklarla bilinçli bir etkileşimi söz konusudur ${ }^{15}$. Onun bu etkileşimi, bizzat kendi hür iradesiyle gerçekleşir ki, buna da insan özgürlüğü denir. Zira özgürlük, insan iradesinin ne kendisi ne de her hangi bir kişi veya şey tarafından engellenmemesi ya da her hangi bir davranışa zorlanmaması durumudur. Yani özgürlük, kişinin, kendi inanç, fikir ve davranışlarını her hangi bir engel, baskı ve müdahale olmadan kendi tercihleriyle belirlemesidir. Bu yüzden özgürlük, insanın, öncelikle Allah'tan başkasına kul olmaması ve nihayetinde içgüdü ve tutkularının güdümünden kurtulması demektir. Zira o, aklını kullanabilen, davranışlarını bilinçli 
ve iradeli bir şekilde belirleyebilen bir varlıktır ${ }^{16}$. Ayrıca insan, doğuştan getirdiği potansiyeli fizikî, fikrî ve ahlâkî bağlamda inkişaf ettirebilen yegane canlıdır. Bu anlamda onun özgürlüğü, içgüdülerini kontrol altına alabilme ve medenî hayata katılabilmesidir. Işte burada Tevhid inancı, insanın, kendi idrak yolları üzerindeki kibir, önyargı ve çevrenin etkisini yok edip, özgürlüğünü tam temin etmek suretiyle sürece katılmış önemli bir etkendir.

İslam'a göre, varlık hiyerarşisi içerisinde değer itibariyle, Yüce Allah'tan sonra gelen en önemli varlık insanoğludur. Yani, yaratılmışlar arasında ondan daha kıymetli görülen başka bir varlık yoktur. Bundan dolayıdır ki, "insanın varlığa karşı tutum ve davranışı nasıl olmalıdır, görev ve sorumlulukları nelerdir?" gibi sorular, insanın özgürlüğü çerçevesinde ele alınmış meselelerdir. Bu yönüyle denilebilir ki, özgürlüğün mahiyet ve sınırlarının tespiti, ancak bütün diğer varlıkların konum ve değeri hesaba katılarak yapılabilir. Tam bu yüzden tarih boyunca insanlığın oluşturmuş olduğu şuur altı birikiminde özgürlük kavramının daima varlıklarla ilintili ve insan merkezli ele alındığı görülmektedir. Dahası, "insanoğlu özgür müdür?", "özgürlüğü kime veya neye karşıdır?"ya da "bu özgülügün sınırları nerede başlar ve nerede biter?" gibi sorular İslam inancı içinde de ele alınmıştır. Biz de bu çalışmamızda, insan özgürlüğü ve bu özgürlüğün, İslam'ın ana konusu tevhid ile ilişkisini ele aldık. Yani öncelikle tevhid inancının, insan özgürlüğünü kısıtlayıp kısıtlamadığı, daha sonra insanın gerek kendine gerekse diğer varlıklara karşı özgür olup olmadığı, eğer özgürse bu özgürlüğün nasıl olması gerektiği, sınırların nerede başlayıp nerede bittiği ve tevhid inancının, bu duruma olan etkisini inceledik.

\section{Tevhid-Özgürlük İlişkisi}

Tarih boyunca insan özgürlüğü açısından tartışılan en temel konulardan biri, Allah'ın, sonsuz ilim, irade ve kudretinin yanında insanın bireysel otonomisinin mümkün olup olmadığı olmuştur. Yani her şeyi bilen ${ }^{17}$, her şeye gücü yeten ${ }^{18}$ veya olmamasını irade ettiği zaman da hiçbir şeyin olma ihtimali olmayan ${ }^{19}$ bir Yaratıcı'ya rağmen, her zaman insanoğlu, kendi eylemlerini özgür bir şekilde irade edip yapmaya güç yetirebilir mi sorusu, beşerin en kadim tartışmalarından 
biri olmuştur ${ }^{20}$. Dolayısıyla beşerin en önemli meselelerinden biri, insan iradesi ile Yüce Yaratıcı'nın iradesini örtüştürmek olmuştur.

İslam'a göre, tevhid inancının bağlantılı olduğu temel kavramlardan biri insan özgürlüğüdür. İslam'da tevhid inancıyla insan hürriyeti arasında çok önemli bir ilişki söz konusudur. Müslüman kültüründe özgürlük, hürriyet kavramıyla ifade edilmiştir. Bu kavram, genel olarak kölelik, determinizm ve fatalizmin karşıtı olarak kullanılmıştır. Tevhid, dininin temel inanç esası olarak kabul edilmiş olup, aklî nazar ve vahiyden alınan diğer inanç meselelerinin merkezine oturtulmuştur ${ }^{21}$. Bu akide, ne Hristiyan üçlemesindeki gibi akla ve mantığa ters düşen bir kavram ne de insan ürünü fikirlerde olduğu gibi nakilden uzak bir düşüncedir. Yani o, hiçbir tarafın birbirine baskın gelmediği, akıl ile vahyin yol göstericiliği doğrultusunda denge bir noktayı ifade eder.

Müslümanlar arasında tevhid inancı ve insan özgürlüğü ilişkisi bağlamında üç temel görüş ortaya çıkmıştır²2. Birincisi, cebrî anlayıştır ki, bu görüşe göre insanın kendi eylemlerinde ne iradesi ne de gücü söz konusudur. Bu görüşe göre insan, belirlenen davranış kalıplarını yapmaya mecburdur. İkincisi, mutlak özgürlük anlayışıdır ki, bu görüşe göre insan, kendi eylemlerini yapmada hürdür. Buna göre insanın, ilâhî iradeden bağımsız bir iradesi ve gücü söz konusudur ki, kişi, kendi eylemlerini bu irade ve güç sayesinde gerçekleştirmektedir. Bu görüşe göre kişinin, sorumlu olabilmek için mutlak anlamda irade ve kudretinde özgür olması gerekir²3. Üçüncüsü ise, ilk iki görüşün sentezi olan anlayıştır ki, bu düşünceye göre insan, kendi fiillerini yapmada mutlak değil, nispî (göreceli) bir irade ve güce sahiptir. Yani insanın farklı seçenekler arasından tercihte bulunmasına elverişli bir iradesi ve bir eylemi yapmak üzere iken tam tersini de yapmaya imkân veren bir gücü söz konusudur ki, bunlar da insan eylem ve sorumluluğunun temelini teşkil etmektedir. Bu grup, eylemlerinin seçimini insana, yaratmasını ise Allah'a havale eder. Yani insan davranışları, yaratma bakımından Allah'a, kesb ve karar bakımından ise kişiye nispet edilir. Dolayısıyla insan davranışlarında etkin

21 Muhammet Raşit Batur, Zeydilik ve Selefilik Arasında Ibnü'l-Vezir, (Ankara: Gece Akademi Yay., 2018), 178.

22 Cüneyd Aydın-Ahmet Genç, "SÜNNETULLAH VE INSANIN İRADESi TEMELINDE KADER", JOMELIPS, Cilt 1, Sayı 1, Sayfa: 74-103. 
olan iki irade söz konusudur. Bu fiiller, sonuçları bakımından ilahi iradeye, seçim ve sebepleri açısından ise insan isteğine dayandırımıştır ${ }^{24}$. Ancak fiillerdeki bu ortaklık, insan sorumluluğunu ortadan kaldırmaz. Bununla beraber, bu görüşe göre, insan iradesi ve gücü ile eylemleri arasındaki ilişki, "mutlak sebeplilik" prensibi değil, "iktiran" ilkesi çerçevesinde gerçekleşir. Şöyle ki, sebep-sonuç arasında gerçek illiyet değil, ardardalık münasebeti yani sebepler, sonuçlar için mutlak anlamda olmazsa olmaz neden değil, zamansal açıdan bir birliktelik söz konusudur. Sonuç olarak bu ekol, Yüce Allah'ın, yegâne yaratıcı olduğuna ve iradesinin her şeyi kuşattığına gölge düşürmemek için insanın irade, güç ve hürriyetini en asgari düzeye indirmeye çalışmıştır.

İslam dinine göre, özgürlük bakımından, insan ve Yüce Yaratıcı arasındaki ilişki, ancak iki varlığın ontolojisi, konumu ve varlık sınırlarını bilmekle açıklanabilir. Bu dinde insan ontolojisini izah eden temel kavram fitrattır ${ }^{25}$. Bu kavram, insanın özünü, kapasite ve sınırlarını ifade eder. Aslında fıtrat, insan ile Allah arasındaki farklıı̆ı belirtmek için kullanılır. Bir şeyi yarmak ve ortadan uzunlamasına ayırmak suretiyle yeni bir şey yaratmak anlamına gelen fıtrat ${ }^{26}$, Yüce Allah'ın, kendi mahiyetinden farklı olarak yarattığı ve bir takım kuralları onun mahiyetine yerleştirdiği varlıktır. Dolayısıyla insanın özgürce iş yapabilmesi, ancak fıtrat çerçevesinde mümkündür.

İslam'da insan özgürlüğünün sınırlarını tayin etmede kullanılan temel kavram, takdir kelimesidir ${ }^{27}$. Bir şeyin miktar ve niceliğini belirlemek anlamına gelen bu terim ${ }^{28}$, varlığın yapısına yerleştirilen ölçü̈29 ve kurallar bütünüdür ${ }^{30}$. Takdir kelimesi Kur'an'da Yüce Allah için kullanıldığında; ya kudret vermek ve bahşetmek ya da hikmetin gerektirdiği şekilde varlıkların belli bir ölçü, yol ve maksat üzere olmalarını sağlamaktır. İnsan için kullanıldığında ise; ya bir işi, aklını kullanarak tefekkür edip sonuçlandırmak ya da bir meseleyi nefsi isteklerine göre temenni ederek neticelendirmektir ${ }^{31}$. İslam'a göre, insanın özgürlüğü, ilahi iradenin, be-

Ebu Mansur el-Maturidî, İslam İnanç Esasları (Fıkh-ı Ekber Şerhi), çev. Adnan Bülent Baloğlu-Murat Memiş, (Ankara: İsveç Diyanet Vakfı, 2013). 28.

25 Rum, 30/30.

26 Rağıb el-i̇sfahanî, Müfredat, çev. Yusuf Türker, (İstanbul: Pınar Yayınları, 2002), 105.

$27 \mathrm{~A}^{\prime} \mathrm{la}, 87 / 3$.

28 Hicr, 15/21;el-İsfahanî, Müfredat, 1182.

29 Talak, 65/3.

30 Düzgün, "Varlık", 205.

31 el-İsfahanî, , Müfredat, 1182-1184. 
şeri iradeyi tamamen kontrol altına almadan, ona imkan vererek gerçekleşen bir takdirdir. Bu bağlamda, İslam'da tevhid ilkesi, bireyin otonomisi ve özgür iradenin öne çıkması gerektiğini öğreten temel bir prensiptir. Bundan dolayı özgürlük, insanın, hiçbir varlığa tapar derecede bağlanmadan fıtrat ve takdir sınırları dahilinde sadece Allah'a kulluk etmesi anlamına gelir.

Evrenin ontolojisine bakıldığında Yüce Allah'ın, her bir varlık için bir kemal nokta tayin ettiği ve o şeyin de o hedefe doğru hareket etmek üzere sanki manevi emir almış gibi bir eğilim içinde olduğu anlaşılmaktadır. Zira kâinatın bütün atom ve unsurları gerek tek başına gerekse toplu bir şekilde Allah'ın vaz ettiği kanunlara uyarak muayyen olan vazifelerini ifa ederken, sadece özgür irade sahibi insanoğlu, bu durumun bir istisnası olarak kendisine verilen görevi eksiksiz yerine getirmediği görülmektedir ${ }^{32}$. O, gerek kelam sıfatından gelen emirlere gerekse irade sıfatı tarafından vaz edilen kanunlara uyma konusunda özgür bırakılmıştır. Emir ve yasaklara kayıtsız şartsız uyan bir varlık değildir ${ }^{33}$. Yani o, önceden kurulu bir programa değil, bilgi ve bilincine dayanarak hareket eder. Ancak yine de bir canIı olarak onun en temel özelliklerinden biri, fıtratını gerçekleştirme hususunda gösterdiği çabadır. Yani o, tabiatının gereğini yerine getirirken engelleri aşmak ister. Nasıl ki, bir parça su, donmak istediğinde demiri parçalarsa, bir çekirdek, sümbüllenip ağaç olma arzusunu taşıdığında, kendin gerçekleştirirse, insan da aynı şekilde kendi yaratılış arzusunu ve var olma güdüsünü gerçekleştirmek ister. Ancak onun bu isteği fıtratın kanun ve ölçüleri dışında olamaz. Onun için insanın sonsuz istekleri, ancak kendisine takdir edilen fiziki, biyolojik ve sosyolojik kurallar dahilinde tahakkuk edebilir. Onun, bu kuralların sınırlarını aşacak şekilde birtakım arzuları olsa da gerçekleşmesi mümkün değildir. Çünkü bu istekleri, fıtrat ve takdirin ölçü ve sınırlarını aşmaktadır. Onun için bir canlı olarak insanın özgürlüğü, sonsuz ve sınırsız değil, sonlu ve sınırlıdır.

İslam'a göre Yüce Yaratıcı, evrendeki determinasyonun üstünde ve dışındadır ${ }^{34}$. Halbuki insan da dahil her varlık, bu determinasyonun içindedir ${ }^{35}$. Bu belirlenim, insan özgürlüğünün hareket alanıdır. Zira insan iradesinin tahakkuku için olayların sebep-sonuç ilişkisi dahilinde veya belli benzerlik ve farklılıklar içinde sürmesi

34 Hamide Ulupınar, Ahmet Zerrûk (Hayatı, Eserleri ve Tasavvufí Görüşleri), (İstanbul: Gelenek Yay., 2017), 268. 
gerekir $^{36}$. Zira insanın sorumluluğu, daha önceden belirlenmiş evrensel kurallar çerçevesinde onun bilgi, irade, güç ve özgür seçimine bağlı olarak gerçekleşen fiillere bağlıdır ${ }^{37}$. Bu durum bir ayette: "Sonra da nasıl davranacağınızı görmemiz için onların ardından sizi yeryüzünde halifeler kıldı $k^{\prime \prime 38}$ şeklinde ifade edilmiştir. Bu ayette ifade edildiği gibi insan eylemlerinin, kendi bilgi ve bilincine bağlı olduğu vurgusu yapılmıştır. Başka bir ayette: "Allah, herkesi, ancak gücünün yettiği ölçüde mükellef tutar. Herkesin kazandığı (hayır) kendine, yapacağı (şer) de kendinedir"139 şeklinde ifade edilerek, insanın ancak gücünün yettiği kadarından sorumlu olduğu vurgulanmıştır. Diğer bir ayette ise:"Bir toplum kendilerinde olanı (iyi yönde) değiştirmedikçe, Allah onlardakini değiştirmez" şeklinde buyurularak toplumda meydana gelen değişimlerin, kendi yaptıklarına bağlı olduğu dile getirilmiştir. Sonuç olarak bu ayetlerde, insanda bilgi, irade ve gücün varlığı, onun davranışlarında özgür olduğu ve dolayısıyla yaptıklarından da sorumlu tutulacağı gerçeği ifade edilmiştir.

İslam'a göre tevhid inancı açısından insan özgürlüğü başlı başına bir değer ${ }^{40}$ ise de, nihaî bir değer değildir. Çünkü insan, ne boşuna yaratılmış ne de başıboş bırakılmıştır ${ }^{41}$. Işte bu yüzden bireyin yaşamına hiçbir gücün karışamaması anlamında kullanılan özgürlük, tevhid inancıyla bağdaşmamaktadır. Çünkü eğer insan, yaratıcısını inkâr ederse, başta kendisi olmak üzere her bir varlığı ilahlaştırmış olmaktadır ${ }^{42}$. Halbuki sadece Yüce Allah, kemal sıfatlarıyla muttasıf olup ilah olmaya layıktır. O'nun dışındaki hiçbir varlık, gerçek anlamda kemal sıfatlara haiz olmadığından ilah olmaya da layık değildir. Zira O'nun vasıflarını insana veya diğer varlıklara atfetmek büyük bir paradoks oluşturur. Çünkü vacip varlık olan Allah ile mümkün varlıklar arasında herhangi bir benzerlik söz konusu değildir ${ }^{43}$. Dolayısıyla kulu kul olarak, Rab'ı ise Rab olarak isimlendirmek ontolojik açıdan en doğru yargıdır. Zira Yaradan ile yaratılanın eşdeğer görülmesi duru-

\section{kültesi Dergisi, 20(2012), 8.}

37

38

Yunus, 10/14.

Bakara, 2/286.

Kıyame, 75/36.

İhlas, 112/1-4.

Yusuf Şevki Yavuz, "Kader", İslam Ansiklopedisi, XXIV, 58-63).

Hasan Onat, "Özgürlük Bağlamında Din Anlayışındaki Farklılaşmalar ve Mezhepler", İslâmi Araştırmalar = Journal of Islamic Research, 2018, cilt: XXIX, sayı: 2, s. 169-192.

Karl Jaspers, Felsefe Nedir?, trc. İ. Zeki Eyuboğlu, (İstanbul: Say Yayınları, 1986), 71. 
munda, Yaradan'ın, yaratıcılık vasfını kaybetmesi ve insanın yaratıcılık özelliğini kazanması anlamına gelir ki bu durum, iki varlığın ontolojisini de tartışmalı hale getirir.

İslam’a göre insan, ontolojik olarak ayrıcalıklı bir varlık olduğu gibi Allah'ın ona yüklediği görev ve sorumluluk açısından da belli bir onura sahiptir ${ }^{44}$. İnsanın değerli ve onurlu olması, onun özgür olmasını gerektirir. Zira ilâhî irade karşısında özgürlük ve otonomiye sahip olmak, onur, değer ve haysiyeti beraberinde getirir. Ancak yaratılışta insan, değerli kılınmakla birlikte, belli bir süreç içinde ve kendi çabasıyla varoluşunu gerçekleştirecek bir birey olarak başlangıçta "nötr" bir durumdadır. Başka bir ifadeyle o, kimlik ve kişilik sahibi olmaya doğru gittikçe öz benliğini oluşturur ve kendi değerini kazanır. Onun, bu süreçte kendi onurunun bilincine varması ve kişiliğini oluş̧turması özgürlüğe bağlıdır. Birey olarak kişi, kendini ve Yaratıcı'sını tanıdıkça ${ }^{45}$ ve çevreyle ilişki kurdukça benliği açığa çıkar ve gelişir. Bu bakımdan insanın kendini tanıması ve dolayısıyla kendini bizzat kendisinin inşa etmesi, Yaratıcı'sını bilmesi ve diğer varlıklarla doğru ilişki kurması, ancak özgürlüğü sayesinde mümkündür. Bu durum Kur'an'da: "Allah'ı unuttular da Allah da onlara kendilerini unutturdu"46 şeklinde ifade edilerek, insanın kendini keşfetmesinin, ancak aşkın bir varlıkla bağ kurarak mümkün olabileceğini vurgulamıştır. Aslında Allah'a iman, tüm yaşamın nihaî ve manevî temeli olduğundan, zımnen insanın, kendi ideal tabiatına bağlılık demektir ${ }^{47}$. Dolayısıyla bireysel özgürlük ve insan onuru arasındaki karşılıklı nedensellik, İslam’ın nazarında insanın anlam ve değerinin iyi tespit edilmesini gerektirmektedir. Onun için Kur'an, emaneti yüklendiğini belirterek ${ }^{48}$ insana hem verilen özgürlüğün önemini vurgulamış hem de çok önemli bir sorumluluk yüklemiştir ${ }^{49}$.

Tin, 95/4; Allah'ın Adem (a.s.)'i kendi elleriyle yarattığını ifade etmesi (Sâd, 38/7) insan için bir onurlandırmadır. Yine: "Insanoğlunu şerefli kıldık. Onları karada ve denizde taşıdık. lyi ve temiz şeylerle rızıklandırdık. Yine onları yaratıklarımızın birçoğundan gerçekten üstün kıldık." (İsrâ 17/70.) ayeti de insanın değerini, evrendeki tüm diğer varlıklar karşısındaki üstünlük ve önceliğini ifade etmektedir. Hamide Ulupınar, "ilk Dönem Sufilerinde Tevhid Anlayışı.” Tasavvuf Dergisi 22 (2008), 235-255. Haşr, 59/19. Muhammad Ikbal, The Reconstruction of Religious Thought in Islam, (Lahore: 1989), 117. 


\section{Ahlak-Özgürlük İlişkisi}

Ahlak, hulk (huy) kelimesinden türemiş olup ${ }^{50}$ sözlükte, doğru bir biçimde ölçmek, huy ve karakter gibi anlamlara gelir. Terim olarak ise, bir nesneyi hiçbir asıl ve köken olmadan ve herhangi bir şeyi örnek almadan meydana getirmek demektir ${ }^{51}$. Bir başka ifadeyle ahlak, bireyin, toplum içindeki her türlü davranışını ve onun diğer insanlarla olan ilişkisini düzenlemek maksadıyla ortaya konulan ve yasalarla belirlenmeyen adab-ı muaşeret kurallarıdı ${ }^{52}$.

İslam’ın ana kaynağı Kur'an-ı Kerim'e göre ahlaki açıdan insanın, bazen kendi içindeki duygulara karşı özgürlüğünü koruyamadığı ve hatta kendini ilahlaştırdığı dile getirilmiştir. Kur'an'da bu durum: "Hevasını ilah edinenleri gördün mü? Ona

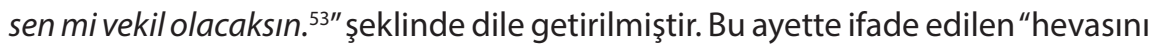
ilah edinmek" cümlesinin ne anlama geldiği, nefsin ilahlığının nasıl gerçekleştiği veya kişinin ne yaparak kendini ilahlaştırmaması gerektiği gibi sorulara verilecek cevaplar, aslında insan özgürlügünün mahiyet ve sınırlarını belirler. İslam ahlak felsefecilere göre, genelde insan nefsinin akıl, gazap (öfke) ve şehvet (aşırı istek) denilen üç temel gücü vardır ki, bunlar aslında insanda irade, seçim, görev ve sorumlulukları kapsayan özgür eylemlerin kaynağını oluşturmaktadır ${ }^{54}$. Bu kuvvetlere dinen bir sınır tayin edilmiş ise de, ontolojik olarak tayin edilmediğinden, onların her biri ifrat, tefrit ve vasat namılla üç mertebeye ayrılmaktadır ${ }^{55}$.

İnsandaki şehevî güç, menfaatleri elde etmeye yarayan kuvvedir ${ }^{56}$. Bu duygunun ifrat mertebesi fücurdur (şehvet düşkünü) ${ }^{57}$. Bu mertebede kişi, başkasının namus ve ırzına zarar verme eğiliminde olur. Şehvet duygusunun tefrit mertebesi humuddur (şehvet hissinin körelmesi, soğukluk ${ }^{58}$. Bu aşamada kişinin, ne helale ne de harama karşı şehvet ve iştihası yoktur. Şehevî duygunun vasat mertebesi ise iffettir. Iffetli kişi, helal olan şeylere karşı istekli olurken, haram olan şeyle-

Nasiruddin et-Tusî, Ahlak-ı Nasirî, çev. Anar Gafarov, Zaur Şükürov, (İstanbul: Litera Yayıncılık, 2007), 81.

Kınalızade Ali Çelebi, Ahlak-ı Alâîi, haz. Mustafa Koç, (İstanbul: Klasik Yayınları, 2007), 93.

Hüsameddin Erdem, Ahlak Felsefesi, (Konya: Hü-Er Yayınları, Konya 2009), 15.

Furkan, 25/43; Casiye, 45/23.

et-Tusî, Ahlak-ı Nasirî, 36-37.

Nursi, Işaratü'l-I'caz, 32-33.

Alaüddin el-Kazerunî, Şerhu'l-Ahlaki'l-Adudiyye, (İstanbul: Türkiye Yazma Eserler Kurumu Başkanlığı Yayınları, 2014), 46.

Çelebi, Ahlak-ı Alâî̀, 113-114.

Ebû Hamid Muhammed el-Gazalî, İhyau Ulumu'd-Din, trc. Sıtkı Gülle, (İstanbul: Huzur Yayın-Dağıtım, 1998), III, 119. 


\section{Maksut ÇETIN \\ İslam Dininde Tevhid-Özgürlük İlişkisi}

re karşı ise mesafeli olur ${ }^{59}$. Bu kuvvetin denge noktası olan iffet, şehevî duygunun hikmet, akıl ve dinin kontrolü altında olmasıdır. Yani iffet, şehvet gücünün, frenlenip istikamet üzere yönlendirilmesi ${ }^{60}$ veya aklî kuvvenin kıstaslarına göre hareket etmesidir. Böylece şehevî duygunun boyunduruğu altına girmeyen kişi, gerçek özgürlüğü yaşamış olur ${ }^{61}$. Aksi durumda kişi, bu kuvvenin ifrat ve tefrit çizgisinde bir hayat sürer, o zaman da özgürlüğünü kaybetmiş olur.

İnsandaki gazap (öfke) duygusu, kişiden zararlı şeyleri uzaklaştıran kuvvedir. Bu güç, zararları def etme, korkulan şeyleri yok etme, otorite ve üstünlük kurma ve makam mansıba karşı olan istek ve arzuların kaynağıdır ${ }^{62}$. Bu duygunun ifrat mertebesi tehevvürdür (aşııı kızmak) ${ }^{63}$. Bu mertebede kişi, maddî ve manevî hiçbir şeyden korkmaz ve dolayısıyla birçok zulüm işler. Gazap duygusunun tefrit mertebesi cebanettir (ödleklik) ${ }^{64}$. Bu aşamada kişi, korkulmayan şeylerden bile korkar. Bu duygunun vasat mertebesi ise şecaattir (cesaret). Şecaat sahibi kişi, özgür iradesiyle dinî ve dünyevî hukuku için canını feda eder, meşru olmayan şeylere ise karışmaz. Aslında şecaat, öfkenin itidali, orta noktası ve dolayısıyla öfke duygunun yaratılış amacına uygun kullanılmasıdır ${ }^{65}$. Bu sıfata sahip olan kimse, hem kendi haklarını hem de başkalarının haklarını korur. Zulüm ve sömürü karşısında sesini yükseltir.

Son kuvve olarak akıl ise, ifadelerde doğru ile yalanı, inançta hak ile batılı, eylemlerde güzel ile çirkini ayırt eden kuvvedir ${ }^{66}$. Bu duygunun ifrat mertebesi cerbezedir (sefihlik) ki, kişi, bu aşamada hakkı batıl, batılı hak gösterecek kadar aldatıcı bir zekâya sahip olur. Akıl duygusunun tefrit mertebesi gabavettir (beladet, aptallık) ki, kişi, bu aşamada düşünme ve akli işlevler açısından son derece zayıf bir konumda olur. Akıl gücünün itidal noktası ise, hikmettir. Hikmet, hakkı hak olarak algılayıp onun ölçülerine uygun hareket etmek ve batılı da batıl olarak görüp ondan uzak durmaktır. Sözün özü hikmet, bütün iradî fiillerde, doğruyu yanlıştan ayıran

60 Mustafa Çağrıcı, İslam Düşüncesinde Ahlak, (istanbul: Dem Yayınları, 2012), 131.

61 Ahmed b. Muhammed İbn Miskeveyh, Tehzibu'l-Ahlak (Ahlak Eğitimi), (İstanbul: Büyüyenay Yayınları, 2013), 34.

62 el-Kazerunî, Şerhu'l-Ahlaki'l-Adudiyye, 44.

63 el-Gazalî, ihyau Ulumu'd-Din, III, 119.

64 Akseki, Ahmed Hamdi, Ahlak Dersleri, (Ankara: Diyanet İleri Başkanlığı Yayınları, 2016), 225.

65 el-Gazalî, ihyau Ulumu'd-Din, III, 119.

66 Ebû Nasr, el-Farabî, İdeal Devlet, çev. Ahmet Arslan, (Ankara: Divan Kitap Yayın., 2012), 73. 
aklî duygunun vasatıdır, denilebilir ${ }^{67}$. Zaten Yüce Allah Kur'an'da: Kime hikmet verilmişse, işte ona pek çok hayır verilmiştir" ${ }^{\prime \prime 8}$ diyerek bu hakikati dile getirmiştir.

Sonuç olarak şehvet, gazap ve akıl denilen bu üç temel duygu, insanın mahiyetinde işler görecek iradi eylemlerin meydana gelmesine kaynaklık eder. Bu güçlerin vasatı adalet, ifrat ve tefriti ise zulümdür ${ }^{69}$. Insan, bunların denge noktasında kaldığı sürece gerçek hürriyeti yakalamış ve yaşamış olur. Ifrat ve tefrit çizgisinde yaşadığı zaman ise, özgürlük zannettiği ama aslında esaretin ta kendisi olan bir duruma düşer. Çünkü insan, aşırı uçlarda yaşadığı zaman fıtratından saparak kendine zulmetmiş olur. Bu durum ise Kur'an'da şu şekilde ifade edilmektedir: “Şüphesiz Allah hiçbir şekilde insanlara zulmetmez. Fakat insanlar kendilerine zulmederler"70. Bu ayette ifade edildiği gibi zulüm, kişinin, bu üç duygunun vasatından saparak ifrat ve tefrite kayması veya o kuvvelerden birinin güçlenip ötekilere zarar vermesi yahut birinin ötekilerin etkisini yok etmesi durumunda meydana gelir. Dolayısıyla özgürlük, insan nefsindeki öğelerin kendi aralarında bir denge oluşturması $^{71}$ veya onların vasat noktada kalması durumudur. Ayette ifade edilen "nefsin ilah edinmesi"72, insanın, bu duyguların vasatından uzaklaşarak ifrat veya tefrit çizgisinde bir hayat sürmesi anlamına gelir. Aksi halde insan kendini özgür zannederken, tam bir köle durumuna düşer. Zira davranış alanında gerçek özgürlüğü elde etmek için tevhid inancını etkinleştirerek aktif hale getirmek gerekir. Bu da nefsin hevasına uymak yerine, İslam dinine ve aklın temel ilkelerine tabi olmakla olur. Bu durum, bir ayette şöyle dile getirilmiştir: "Şüphesiz bu (İslâm), benim dosdoğru yolumdur. Artık ona uyun, başka yollara (dalâlet yollarına) uymayın. Yoksa o yollar sizi parça parça edip O'nun yolundan ayırır"73. Bu ayette ifade edildiği gibi Allah'ın yoluna uymak, nefsin isteklerine gem vurmak ya da o istekleri istikamet üzere sürdürmek demektir. Çünkü gerçek anlamda insanın ne hayatı kendisine ait ne de ölümü kendi elindedir, tam tersine her ikisi de Yüce Yaratıcı'nın tasarrufundadır ${ }^{74}$. Onun için kişi, ne ibadetlerinde ne de hayatında istediği gibi özgürce tasarruf etme hakkına sahip değildir. Çünkü ibadeti vazeden ve sınırlarını belirleyen Allah olduğu gibi hayatı ve ölümü var eden de O'dur.

el-Gazalî, Ihyau Ulumu'd-Din, III, 120.

Bakara, 2/269.

Raşit Çavuşoğlu-Hamide Ulupınar, Bekir Sıdkı Visâlînin Sohbetleri, (Ankara: Ilâhiyât Yayınları, 2020), 62.

Yunus, 10/44.

el-Kazerunî, Şerhu'l-Ahlaki'l-Adudiyye, 34; İbn Miskeveyh, Tehzibu'l-Ahlak (Ahlak Eğitimi, 66.

Furkan, 25/43.

En'am, 6/153.

En'am, 6/162. 


\section{Diğer Varlıklar-Özgürlük İlişkisi}

Ontolojik olarak özgürlük soyut bir kavramdır. Ancak kendi çabası ile sahip olduğu ifade tarzı ve eylem şekilleri sayesinde insan, özgürlüğü somut bir şekilde yaşar. Mesela sevmek, nefret etmek, kıskanmak ve takdir etmek gibi duygu durumları, diğer bazı canlılarda da gözlemlenebilir. Fakat sadece insan, bu tür duygu ve düşünceleri farklı tarz ve yöntemlerle ifade edebilir veya eylemlere dönüştürebilir. Bu yönüyle özgürlük, soyut bir kavram olsa da, sonuçta insanın somut bir eylemi olarak yaşanmaktadır. Çünkü o, duygu, düşünce ve eylemlerini istediği şekilde ifade edebilme ve yaşayabilme özgürlüğüne sahip bir varlıktır. Böylece soyut bir özellik olmasına rağmen özgürlük, somut yaşanan bir ilke olarak insanın hayatında yer alır.

İslam'a göre, mümkün varlıklar içerisinde, özgür irade sahibi yegâne varlık insanlarla cinler ${ }^{75}$ olsa da aslında hürriyet denilince akla gelen ilk varlık insandır. Bu yüzden insanın diğer varlıklarla ilişskisi, bu ilişkinin düzey ve sınırları, tevhid inancının bu ilişkiye yansımaları insanlığın ve Müslümanların en temel sorunlarından biridir. İslam dinine göre insanın yeryüzüne halife olması ve varis kılınması ${ }^{76}$, ona eşyaya dair isimlerin öğretilmesi ${ }^{77}$, yeryüzünün onun istifadesine sunulmuş olması $^{78}$, ayrıca onun toplumun yerleşik adetlerine körü körüne teslim olmaması ${ }^{79}$ veya siyasi ve dini otoritelere kayıtsız ve şartsız bağlanmaması gerektiği ${ }^{80}$ gibi durumlar, onun özgürlük ve sorumluluğunun önemli bir göstergesidir. Ancak İslam dininin ana kaynağı Kur'an- Kerim’de insanoğlunun, bazen ya menfaat ve sevgiden ya da korku ve endişeden dolayı kendi dışındaki birtakım varlıklara karşı özgürlüğünü koruyamadığı veya onları ilahlaştırdığı ifade edilmiştir ${ }^{81}$ ki, bu da onun hürriyetini zedeleyen bir durumdur.

İslam'a göre insan, tüm tercih ve davranışlarından hesaba çekilmek üzere imtihana tabi tutulmuştur ${ }^{82}$. Yüce Allah, her şeyi eşit bir şekilde onun istifadesine

Bakara, 2/30; Fatır, 35/39.

Bakara, 2/31.

Lokman, 31/20; İbrahim, 14/32-33.

En'am, 6/148; İbrahim, 14/10.

Nisa, 4/59.

Furkan, 25/3.

82 Mülk, 67/2. 
sunarak imtihanı adil kılmıştır ${ }^{83}$. Mesela, insana irade, akıl, tefekkür gibi yetenekler vermekle beraber, onu vahiy ile de desteklemiştir. Fakat şeytan, nefis ve içgüdü gibi iç faktörlerin yanı sıra toplumun gelenekleri, dini ve siyasi liderler, ekonomik, ilmi ve sosyal statü gibi dış faktörler kişinin özgürlüğünü ve yapacağı tercih ve eylemlerini etkileyebilmiştir ${ }^{84}$. Dolayısıyla tam bir özgürlükten söz etmek yerine, bir takım kısıtlamaların varlığı söz konusudur. Bu etkenlerin tesirini azaltmak ve insanı kendi tercihleriyle baş başa bırakmak için İslam dini, her şeyi bilen ve her şeye gücü yeten Yüce Allah'ın varlığını insanlığa bildirerek o engelleri bertaraf etmeyi hedeflemiştir. Onun için tevhit ilkesi, yalnızca Allah'ın bir ve tek olduğunu ikrar etmekle kalmamış, aynı zamanda insan özgürlüğünü temin etmek üzere O’nunla aracısız iletişimi de gerekli görmüştür ${ }^{85}$.

\subsection{Bilim-Özgürlük İlişkisi}

Bilim, Yüce Allahın kâinatta vaz ettiği yasaların insan tarafından keşfedilerek meydana getirilmesi sonucu oluşan bir olgudur. Bu olgu sayesinde insan, teknolojiyi üretir. Tevhid dini olan İslam ise, Yüce Allah’ın, insanlar için gönderdiği kurallar bütünüdür. Bu yönüyle, din ile bilimin ortak noktası, kanun olgusudur. Kurallar bütünü olarak dini insanlığa gönderen Yüce Allah, şüphesiz aynı zamanda bilimin üretildiği evrenin yasalarını da vaz etmiştir. Başka bir ifadeyle bilgi ve bilimi üreten insan aklıdır ${ }^{86}$. Bu yeti, aynı zamanda kişinin, dine karşı sorumlu ve muhatap olmasını sağlayan güçtür. Yani akıl, hem evrenin yasalarını keşfeden ve sırlarını çözmeye çalışan bir yetenek hem de dinin muhatabı, ondan sorumlu, onu anlayan ve yorumlayandır ${ }^{87}$. Zaten tevhid dini olan İslam, akıl ve bilgi üzerine kurulmuş bir dindir.

Bakara, 2/29.

İbrahim Yıldız, "Kur'ân-ı Kerîm'de Atalar Geleneği ve İnanca Etkisi", KSÜ Illahiyat Fakültesi Dergisi 26 (2015), 175-216.

Kur'an'da:"Onların yalvardıkları bu varlıklar: "Hangimiz daha yakın olacağız" diye Rableri'ne vesile ararlar. Onun rahmetini umarlar, azabından korkarlar..." (İsra, 17/57) ayetiyle insanın ibadet ve duada Allah ile arasına aracı koyması reddediliştir. Ancak: "Ey iman edenler! Allah'a karşı gelmekten sakının, ona yaklaşmaya vesile arayın ve onun yolunda cihat edin ki kurtuluşa eresiniz." (Maide, 5/35.) ayetinde ise, Allah'a yakınlaşmaya dair vesile, ibadet ve dua olarak açıklanmıştır. (Ayrica bkz. Tevbe, 9/99).

el-i̇sfahanî, Müfredat, 1032-1035.

Hasan Onat, "Özgürlük Bağlamında Din Anlayışındaki Farklılaşmalar ve Mezhepler", İslâmi Araştırmalar = Journal of Islamic Research, 2018, cilt: XXIX, sayı: 2, s. 169-192. 
Tarih boyunca, düşünce özgürlüğü ve bilimsel gelişmeler arasındaki ilişkinin orantısal varlığı şüphesizdir. İnsan, özgür bir şekilde düşündükçe ve düşüncelerini özgürce ifade ettikçe bilimin gelişmesine katkı sağlamıştır. Dolayısıyla özgür düşünce ve bilginin kaynağı olan akıl ile aklın ürettiği bilim ve bilimin ürünü olan teknoloji arasında kaçınılmaz bir bağlantı hep var olmuştur. Bundan dolayı, bilimsel gelişmeler için, olmazsa olmaz temel şart olarak özgürlük dillendirilmiş ise de, bilim, aynı zamanda konu ve metot itibariyle kendini sınırlamış bir alandır. Onun konusu sadece uzayda yer kaplayan fiziksel madde kütlesi, metodu ise bu kütlenin ancak birtakım özelliklerini veya nesneler arasında var olabilecek ilişkilerinin sadece bir kısım türleridir. Dolayısıyla bilim, konu, içerik ve yöntem itibariyle sınırlı bir alandır. Kendisini bu sınıra hapseden birinin dünyası da elbette sadece bilimin elverdiği ölçüde ancak genişler. İşte bu yüzden bilim insanlarının çoğu, zihinsel faaliyetini, bilimin sınırları içinde tuttuğundan, bu sınııın dışına çıkan her türlü eylemi safsata, dogma, inanç ya da irrasyonel olarak isimlendirmişlerdir. Halbuki özgürlük kavramı, bilim insanının, kendine kurduğu bu küçük dünyayı aşar. $O$, anlama çabasıyla beraber insan ruhunun yeteneğidir. Zira kendini bilimin yargılarıyla kısıtlayan bir insan, özgürlüğünü kısıtlamış olur. Başka bir ifadeyle bilimin tanımladığı ve sınırlarını çizdiği dünyaya hapsolan bir akıl, esneyebilme kabiliyetini zayıflatmış olduğundan özgürlüğünü de sınırlandırmış olur. Oysa Yüce Allah'ın en büyük nimetlerinden olan özgürlük, aklı esneten ve olabildiğince daha geniş ve derin bir dünyaya doğru sürükleyen bir güçtür. Dolayısıyla düşünmeyi bilimin nesne ve yöntemiyle belirlemek ve sınırlamak bir nevi onu hapsetmektir ki, bu da, psikoko-fizyolojik olarak özgürlüğün bir çeşit trajedisi anlamına gelir.

Bugünkü bilim, deney ve gözleme dayanarak nesnesi olan evreni anlamaya çalışırken "niçin" sorusundan ziyade "nasıl" sorusunun cevabını arar. "Nasıl" sorusuna verilen cevap, deney ve gözlem aracılığıyla test edilebilir bir özellik taşırken, "niçin" sorusuna verilen yanıt ise, bir gaye öngördüğünden cevabı da teleolojik ve teolojik bir yorum barındırır. Yani niçin sorusunun cevabı, teleolojik ve teolojik bir çerçevede verilebilirken, nasıl sorusunun cevabı, ancak nesnel ve test edilebilir olmalıdır. Onun için bilimsel sonuçlar sadece akıl ve duyular yoluyla meydana getirilirken, tevhide dair meseleler daha çok akıl ve vahiy aracılı̆ı̆ıla elde edilir. Ayrıca günümüz fiziksel bilimin evrene dair cevabı, insan ve toplum için de geçerli kabul edilerek bilimsel bir zihniyet oluşturmuştur. Öyle ki, bu durum, günlük yaşama kadar uzanarak inanç ve düşünmeyi bile esir almış ve dolayısıyla insan özgürlüğünün önünde önemli bir set kurmuştur. Ancak bilimsel düşünce 
ile "nasıl" sorusu arasında bir uyum olsa da, hiç şüphe yok ki insan, metafizik bir varlıktır. 'Niçin' sorusunu sormadan ve onun cevabını bulmadan edemez. Zira bir bilim insanı olsa da, hiç kimse hayatını ve yaşamını, sadece 'nasıl' sorusuyla dolduramaz. Çünkü beğeni, inanç ve tercihlerimizi bütünüyle bir kenara bırakarak hareket edemeyiz. Günlük yaşamımızda veya profesyonel olarak yaptığımız bir işte bile bir noktadan sonra mutlaka 'niçin' sorusunu sorarız. Fakat açıkça görülebileceği gibi bilimsel cevap, 'niçin' sorusuna değil, 'nasıl' sorusuna bağlıdır. Elbette metafizik bir yönü olan ve inanan bir varlık olarak insan, hiç kuşku yok ki "niçin?" sorusunu bir kenara atarak yaşamını sürdüremez. Çünkü bilginin kaynaklarından biri olan akıl, sadece 'nasıl' sorusuna değil, niçin sorusuna da cevap bulmayı isteyen bir yetimizdir. Onun için tevhid dini İslam, insanı, metafiziksel konularda aydınlatmak gayesiyle duyu ve aklı desteklemek ve yönlendirmek üzere vahiy bilgisini göndermiştir.

İslam'a göre Yüce Allah, insanı, akıl ve bilgi ile diğer varlıklardan üstün kılmıştır ${ }^{88}$. Akıl ve bilgiyi kullanmamak ilahî ikramı heba etmek, nimetin değerini bilmemek demektir. İslam'da insan özgürlüğü ve düşüncenin kaynağı olan akıl ile bilgi arasında yakın bir ilişki söz konusudur ${ }^{89}$. Düşüncenin kendine seçenek oluşturması, ancak bilgi ile gerçekleşebilir. Bilgi sahibi olmak, seçenek oluşturabilmek, yani düşüncenin özgürleşebilmesi için gereklidir. Zira bilgi, bilgiyi doğurur ve insan yeni düşüncelere yine bilgi aracılığıyla ve bilgiyi kullanarak ulaşır ${ }^{90}$. Bilgi, aynı zamanda eleştirel düşüncenin de ön şartıdır. Bu durumda bilgi, düşüncede yeni alternatifler oluşturulabilme ve dolayısıyla düşüncenin özgürleşmesine olanak veren güçtür. Çünkü özgür insan, etkin ve aktif olması yönüyle akıllı insan demektir. Bu nedenle insanoğlu, akıl ve düşünce bakımından yeterince hür olmalıdır. Anlayış, inanç, düşünce ve niyetlerinde özgür olmaması, onu tam bir köle durumuna düşürmüş olur. Böylesi bir kölelik ise, toplumda çatışmacı ve yıkıcı bir karakter, haksız ve adaletsiz bir yapının oluşmasına yol açar. Bu yüzden Kur'an'da aklın varlık ve neliği yerine fonksiyonu ön plana çıkmıştır. Zira akıl, Müslümanın sürekli ve dinamik eylemlerinin ve bilginin de en önemli kaynağı olduğundan her zaman olumlu ve önemli görülmüştür ${ }^{91}$. Onun için İslam'da aklın bizzat kendisi değil, onun kullanımındaki maksat ve yöntemler tartışmıştır. 
Tevhid dini olan İslam'a göre insanın yeryüzüne halife olması ve kendisine eşyanın isimlerinin öğretilmesi ${ }^{92}$, onun yeryüzünde nesnel gerçekliği gözlemleyerek keşfetmesi ${ }^{93}$, dolayısıyla bilgi, bilim ve teknolojiyi üretmesi gerektiği vurgulanmıştır. Ayrıca İslam, insanın, bilimsel bilgi ve teknolojiyi varlığın tabiatına ve kendi varoluş gayesine uygun şekilde kullanması gerektiğini de ifade etmiştir. Yani İslam dini, bilgi ve ürünlerini birtakım dini ve ahlaki değerlerle harmanlayarak ahlaklı birey ve adil bir toplumsal yapıyı inşa etmek üzere kullanması gerektiğini ifade etmiştir. Böylelikle bilgi, bilim ve teknolojinin sorgulanamaz bir şekilde ilahlaştırılması engellenmiş olur. Onun için İslam, bilgiyi güç ve teknolojiyi de egemenlik aracı olarak algılayan Batı́nın bilim ve teknoloji anlayışından ve tabiata yaklaşımından ayrılmaktadır. Çünkü Batı dünyası bilgi, bilim ve teknolojiyi, sorumluluk ve ahlaki bir anlayıştan uzak bir şekilde kullanarak tabiata müdahale edip hâkim olmaya çalışır. Müslümanlar ise, bütün bu imkânları, sorumluluk bilinci içinde kullanarak hareket etmiştir. Onlarda bu bilinci oluşturan biricik değer, bizzat İslam dini ve temel ilkesi olan tevhid inancıdır.

İslam, bir yandan bilginin araç ve yöntemlerine başvurarak onu elde etmeyi tavsiye ederken, diğer yandan da geçerli yol ve yöntemleriyle ulaşılan bilgi ve görüşlerin paylaşılmasını emreden bir dindir. Bu nedenle görüş açıklamak, yalnızca bir hak değil, bir görevdir ${ }^{94}$. Çünkü bu emir, bilgi ve medeniyetin yükselmesini sağlayan temel argümanlardan biridir. Bunun için Kur'an, hakikatin yegâne kaynağı olarak sadece Yüce Allah'ı ve O'nun mutlak ve her şeyi kuşatan ilmini göstermektedir ${ }^{95}$. Çünkü beşeri bilgi göreli, zamansal ve derecelidir. Bu durum Kur'an'da "Allah bilir, siz bilmezsiniz"96 ve: "Her ilim sahibinin üstünde de daha iyi bilen biri vardır." ${ }^{\prime 97}$ şeklinde ifade edilerek, beşeri bilginin mutlak, herkes ve her zaman için geçerli bir bilgi ve kesin bir hakikat olmadığı dile getirilmiştir ${ }^{98}$. Dolayısıyla beşeri açıdan bakınca, hakikat hiç kimsenin tekelinde olamaz. Zaten tekelci zihniyet, egoizmden kaynaklanır, dejenerasyon ve çatışmaya yol açar. Bu yüzden İslam, bilgiye değil, onun kötüye kullanılmasına karşıdır. Zira zaman zaman billerde Yeni Araştırmalar, (Ankara: Berkan Yayınevi, 2019), 257-273. 
ginin çeşitli stratejilerle insanların bilinçaltını etkileme, beyin yıkama ve yanlış bilgilendirme için de kullanıldığı şüphesizdir. Tevhid dini İslam ise, peygamberlere verilen vahyi bilgiyle, beşerî bilgiyi harmanlayarak insan davranışlarına ahlaki değerlerin kazandırılmasında rehberlik etmiştir. Nihayet, tevhid ilkesi vasıtasıyla insanların vicdanında ahlak, hakikat ve değerlerin sabit olduğu düşüncesi köklü bir şekilde yerleşmiş, dolayısıyla beşeri bilgi ve onun ürünü olan bilim ve teknolojinin kutsanması engellenmiş olunur.

\subsection{Dini Liderlik-Özgürlük ilişskisi}

Din, Allah tarafından gönderilmiş bir olgu olsa da onun anlaşılması ve izah edilmesi başta peygamberler olmak üzere din adamlarıdır. Bu açıdan dini liderlik, din işleri konusunda topluma önderlik yapmak anlamına gelmektedir. Tarihsel olarak en çok müntesibi olan Hristiyanlık dininde hem peygamber $\mathrm{Hz}$. İsa hem de o dinin temsilcileri kabul edilen din adamlarına kutsallık atfedilmiştir. Bunun sonucunda, davranışları eleştirilmeyen bir din adamı sınıfı olarak ruhbanlık meydana gelmiştir. Son ilahi din olan İslam ise, ibadette Yaratıc ile bireyler arasındaki tüm aracıları kaldırmış ve bu yüzden İslam'da, dini hiyerarşi ihdas etme anlamında bir ruhban sınıfı oluşmamıştır ${ }^{99}$. Çünkü Allah'a yakınlaşmak gayesiyle herhangi bir aracı koymak, ilk olarak o dinin temel prensibi olan tevhide aykırıdır. Zira bu prensip, kişiyi kula kulluktan ${ }^{100}$ ve kendisi gibi ölümlü varlıklara bağlı olmaktan kurtarır ki, bu da insan özgürlüğünün en güçlü teminatıdır. Zira özgürlük, her hangi bir kişinin, Allah'la iletişime geçtiğini ve gayb bilgilerine sahip olduğunu ${ }^{101}$, ilahî iradenin kendinde tecelli ettiğini ve mutlak hakikatin temsilcisi olduğunu ileri süren beşerî iradelere bağlanmaktan kurtulmaktır. Dolayısıyla tevhid inancı, insanın gerek gönüllü gerekse baskıyla gerçekleşen vesayetten kurtulup özgürleşmesini temin eden en temel sistemdir. Ancak özgürlüğün önündeki en büyük engellerden biri Hristiyanlarda ruhban (din adamları) sınıfı, Müslümanlarda ise kutsanmış birtakım dini liderler olmuştur. ve ılımlılık) kavramı da ruhbanlığı kaldırmaktadır. (bkz. Hadîd, 57/27. Ebu Dâvud, "Salât" 317; "Edeb" 52).

100 Zümer, 39/17.

101 Halbuki, İslam dinine göre gaybın bilgisi sadece Allah için söz konusudur. Bu durum Kur'an'da şu şekilde ifade edilmiştir: "De ki: 'Göklerde ve yerde gaybı Allah'tan başka kimse bilmez. (Bu konuda bilgiçlik taslayanlar) Onlar ne zaman (öleceklerinin ve sonra) dirileceklerinin şuurunda bile değildirler. (Neml, 27/65). 
Tarihsel olarak İslam dininin anlaşılması için müçtehit kişiler, namaz gibi ibadetlerin edası için ise imamların varlığına olan ihtiyaç yadsınamaz. Fakat ne dinin anlaşılmasında ne de dini ibadetlerin ifasında bu vasıtaların kendi özünde kutsal, eleştirilemez ve mutlak bir hakikatleri yoktur. Onlar birer gölge ve vekil değil, yansıtıcı ve aracıdırlar. İslam'daki tevhid inancının amacı, insan ile Yüce Yaratıcı arasında engel oluşturan ve bireyleri köleleştiren her türlü vasıtanın ortadan kaldırarak böylece insanı özgürleştirmektir. İslam'ın özü ve esası olan tevhid ilkesi gereği, Allah’a güvenen ve teslim olan insan kula, kul köle olmaktan ve özgürlüğü kısıtlayan engellerden kurtulmaktır. Zaten dini anlamda aklını ve gönlünü başkasına bağımlı kılan kişinin tevhid inancı sorunlu olur. Onun için Kur'an köleliği yasaklar ${ }^{102}$, bireyi ve onun özgürlüklerini esas alır. Kur'an'ın köleliğe karşı olan çağrısı yalnızca fiziki anlamda değil, dini, ekonomik, sosyal, siyasal türevleriyle birlikte tüm esaretleri kaldırmaya yöneliktir. Zira tevhid inancının ana kaynağı olan Kur'an, her açıdan bağımsız ve özgürce yaşayan birey ve toplumları hedeflemektedir.

İslam dini, temel prensipleriyle din adamlarına insan ile Allah arasında aracllık etme, dinî düşüncede mutlak otorite sahibi olma, Allah adına karar verme, ${ }^{103}$ halk üzerinde dini ve siyasal vesayet kurma yetkisi vermemiştir. Çünkü onların böyle sıfatlara sahip olması, bireysel özgürlük üzerinde bir tehdit oluşturur. Zira bireyler ya da kurumlar olarak Allah ile insan arasında aracılık yapmak, toplumda ayrıcalıklı bir sınıfı ortaya çıkardığından, böyle bir durum, tevhid inancının adalet ve eşitlik ilkelerine aykırı olur. Bu nedenle Kur'an, Müslümanlardan oluşmuş bir grubun, diğer insanları eğitmek üzere: "Dinde (dini ilimlerde) geniş bilgi elde etmesi"104 gerektiğini söylemiş olsa da, toplumun sıradan üyeleri ile onlar arasındaki mesafeyi, İslam'ın sosyo-politik eşitliğine uygun bir şekilde en aza indirmiştir. ${ }^{105}$ Dolayısıyla İslam'da, din adamları yerine âlimler kavramı kullanılmış, resmi dini kurumlar yerine ise sivil kurumlar ihdas edilmiştir. Ayrıca İslam âlimlerinin,

103 Hristiyanlık inancı, Hz. İsa'nın havarîlere yönelik: "Işte ben dünyanın sonuna dek sizlerle birlikteyim." (Matta, 28/20) sözünden Kilise'nin İsa'nın manevî varlığı ile bütünleştiği ve: "Göklerin egemenliğinin anahtarlarını sana vereceğim. Yeryüzünde bağlayacağın her şey göklerde de bağlanmış olacak. Yeryüzünde çözeceğin her şey göklerde de çözülmüş olacak." (Matta, 16/18-20; 18/18) pasajından da din adamlarının, yeryüzünde neye karar verirse gökte Allah da öyle karar verdiği sonucu çıkartmıştır. Oysa böylesi bir durum, Kur'an'a göre âlim ve din adamlarının rabler edinmesi şeklinde (Tevbe, 9/31) ifade edilerek eleştirilmiştir.

104 Tevbe, 9/122.

105 Fazlur Rahman, Allah'ın Elçisi ve Mesajı -Makaleler I-, trc. A. Çiftçi, (Ankara: Ankara Okulu Yay., 1997), 23. 
siyaset alanında dinî bir yetkiden doğan her hangi bir rolü yoktur. Sadece ilmî yetkinliğe dayalı bir birey olarak dini ve sosyo-politik konulara ilişkin görüş açıklama, bir danışman olarak toplumun maslahatını belirleme ve hukukî ilkelerin tespitine katılma gibi görevleri vardır ${ }^{106}$. Bunun için İslam siyasetinde yöneticiler, din adamları olarak değil, dindar kişiler olarak vasıflandırılmışlardır ${ }^{107}$.

Sonuç olarak İslam, fıtri bir din olarak, akıl ve iradenin hakkını verir. Peygamberler aracılığıyla gönderilen ilâhî mesaj ve akıl arasına başkalarının görüş ve düşüncelerini perde yapmaz. Bireyin ilahî mesajı özümsemesini ve mesajın sahibi olan Allah ile doğrudan iletişim kurmasını ister. Yani İslam'da bireyin dini anlama çabası, mutlak anlamda din adamlarının süzgecinden geçmez. Aksine Kur'an'da, bireyin kendi niyet, inanç ve davranışlarından bizzat sorgulanacağı ve başkasının günahını yüklenmeyeceği gibi ifadelerle bireysel sorumluluklar dile getirilmiştir ${ }^{108}$. Zira İslam, din adamlığı ve aracılık öğretilerini reddederek bireyin değerini ve özerkliğini tanımıştır. Onun için Müslüman toplumlarında ortaya çıkan kimi cemaat ve tarikatlarda görülen, bireylerin hiyerarşik bir yapı içinde lidere bağlanması ve bireyin kendi iradesini liderin iradesine teslim etmesi, bireyin özgürlük ve sorumluluktan kaçması olarak algılanmış ve dolayısıyla tasvip edilmeyerek eleştirilmiştir ${ }^{109}$.

\subsection{Siyaset-Özgürlük Iliş̧kisi}

Siyaset ile özgürlük arasındaki ilişki insanlık tarihi kadar eskidir. Siyaset, insanı eğitmek, yönlendirmek, insanlar arası ilişkileri düzenlemek demektir. İnsanın olduğu her yerde yönetimin varlığından, insan hürriyetinin ontolojisinden ve siyaset ile özgürlük arasındaki münasebetten söz etmek mümkündür. Çünkü yaratılışına sinmiş olan hırs, istila ve inhisar nedeniyle insan, birbirine zulmetme potansiyeline sahip olduğu ve karşılıklı sorun yaşadığı için bazen bir arabulucuya ihtiyaç duyar. Toplumda en etkin ve en güçlü arabulucu ise siyaset kurumudur ${ }^{110}$. Ayrıca bireyler başıboş bırakıldığı takdirde, toplumda anarşizmin ortaya çıkacağı ve herkesin kendine göre bir sistem ile işlerini yürütmek durumunda kalacağı,

107 Nazih Ayubi, Arap Dünyasında Din ve Siyaset, trc. Yavuz Alogan, (İstanbul: Varlık Yay., 1992), 65.

108 Bakara, 2/286; Necm, 53/38-39.

109 İsra, 17/36.

110 Bülent Ünal, “İslam ve Siyaset Üzerine Düşünceler”, DEÜiFD XIII, Kış-IIlkbahar 2001, 162. 
bunun da toplumun yapısını ifsat edip fitnenin umumileşmesine ve toplumun helak olmasına neden olacağından dolayı siyasetin varlığına ihtiyaç duyulmuştur ${ }^{111}$. Bu sebeple ulema, dinin maksatları ve toplumun maslahatlarından hareket ederek, yönetimin varlığını zorunlu görmüştür ${ }^{112}$.

Tevhid dini İslam'ın temel kaynağı Kur'an'da konular, bireylerin özgürlük ve olgunluğu, sağlıklı bir sosyo-politik yapıya kavuşmanın nedeni olarak görüldüğünden birey muhatap alınarak işlenmiştir. Onun için Kur'an inanç, ibadet ve ahlak konularına doğrudan ve ayrıntılı yer verirken, Müslümanların işlerinin kendi aralarında meşveretle çözülmesi, ${ }^{113}$ toplumda adalet ve hakkaniyetle hükmedilme$\mathrm{si}^{114}$ yetki sahiplerine itaat edilmesi, ${ }^{115}$ emanetlerin ehline verilmesi ${ }^{116}$ gibi siyasi konulara, evrensel nitelik taşıyan genel ilkelerin dışında, ${ }^{117}$ teferruata dair çok fazla bilgi vermemiştir ${ }^{118}$. Siyasetin tabiatı değişken olduğundan Kur'an, bütün insanların benimseyebileceği ve her zaman, her yerde uygulayabileceği genel kurallar koymuştur. Böylece, siyasi alanla ilgili genel ilkeleri belirleyen Kur'an, o alanla ilgili tasarrufta bulunma ve teferruatı belirleme hakkını insana ve insanın özgür iradesine bırakmıştır.

İslam'da Allah’ın mutlak ve sorgulanamaz, insanın ise sınırlı bir etkinlik alanı içinde sorumlu bir varlık olduğu inancl ${ }^{119}$, onun bir "emanetçi" ve "bir yed-i emin" konumunda olduğu anlamına gelmektedir ${ }^{120}$. Mülkün gerçek sahibi ve hâkimi olan Allah ${ }^{121}$, doğruluk ve adaletle idare etmek üzere insana kitap, mizan ve de-

111 Nursi, Işartu'l-i'caz, s. 154-155.

112 Ebu'l Yusr Muhammed el-Pezdevi, Usulu'd-Din (Ehl-i Sünnet Akaidi), trc. Şerafettin Gölcük, (İstanbul: Kayıhan Yay., 1994), 268; Sa'duddin Mes'ud b. Ömer et-Taftazani, Şerhu'l-Makasıd, tah. Abdurrahman Umeyre, (Beyrut: Alemu'l-Kutub, 1998), V, 237-238; Fahruddin Muhammed b. Ömer er-Razî, Meâlimu Usuli'd-Din (İslam Inancının Ana Konuları), çev. Nadim Macit, (Erzurum: İhtar Yayıncılık, 1996), 130; Abdulkahir el-Bağdâdi, Kitabu Usulu'd-Din, (İstanbul: 1928), 272.

113 Şura, 42/38; Al-i İmran, 3/159.

114 Nisa, 4/58.

115 Nisa, 4/59.

116 Nisa, 4/58.

117 Muhammed Ammara, Mu'tezile ve Devrim, trc. İbrahim Akbaba-İbrahim Güneş, (İstanbul: Ekin Yay., 2000), 325.

118 Sönmez Kutlu, "Ehl-i Sünnet Siyaset Anlayışının Dinî Temellerinin Sorgulanması", e-Makalat Mezhep Araştırmaları, 1/1, (Bahar 2008), 10.

119 Enbiya, 21/23.

120 Ahzab, 33/72.

121 Cum'a, 62/1. 
miri vererek ${ }^{122}$ yeryüzünü imar etme sorumluluğunu yüklemiştir ${ }^{123}$. Yani onun halife ve varis oluşu tamamen kendi arzusuna bırakılmamış, aksine hak ve adaletle sınırlandırıımıştı ${ }^{124}$. Dolayısıyla siyasî yetki, dinî ve dünyevî açıdan topluluğun menfaati için yerine getirilmesi gereken bir emanet olarak kabul edilmiştir. Başka bir ifadeyle siyasî iktidar, evrensel siyasî ilkelerle kayıtlı ve toplumu temsil esasına dayalıdır. Bu emanet, sosyo-politik açıdan belli kişi ya da guruba değil, toplumun tamamına ait olduğundan, her bir bireyin, eşit ve özgür olarak siyasal yönetime katılma hakkı vardır. Çünkü tüm bireyler, insan olma bakımından Yüce Allah'ın yanında eşit hak ve özgürlüklere sahiptir ${ }^{125}$. Ayrıca İslam'da devletin amacı ve varlık sebebi, bireylerin hak ve özgürlüklerini korumaktır. Bireysel hak ve özgürlükler, başkalarından ya da devletten gelecek muhtemel saldırılardan korunmak için değil, bizatihi doğal ve medenî birer olgu olarak kabul edilmiştir. İslam'da tevhid inancı, mutlak egemenliği Allah'a ait kılmakla ${ }^{126}$ siyaset ve mülkiyet açısından insanın iktidar ve hâkimiyetini izafileştirmiştir ${ }^{127}$. İslam dinine göre yönetim, bireylerin hukukunu korumak ve adaleti gerçekleştirmek üzere yapılan bir akittir. Başka bir deyişle, yönetim mekanizması, kişiye bağlı olmayan, sözleşme temelli ve hukukla kayıtlı bir vasıtadır. $O$ halde, belli bir iktidar gücünü elde eden kişi, emanet ve sorumluluk bilinciyle hareket etmek zorundadır. Dolayısıyla hiç kimse sahip olduğu siyasal güç sayesinde diğer insanlar üzerinde mutlak bir tasarruf ve vesayet hakkına, özellikle de gücü başkalarının zararına kullanma özgürlüğüne sahip değildir. ${ }^{128}$ Çünkü İslam'da siyaset, kutsal kabul edilmediği gibi mutlak anlamda her hangi bir kişi veya zümreye tahsis edilmiş de değildir. Bu açıdan, her hangi bir yönetici veya yönetimin ilahi bir güç ve kudsiyete sahip olduğu söylenemez. Onun için Kur'an, siyaset ve yönetim alanında işaret ettiği ilkelerle kişinin, başkasına köle olduğu ve özgürlüklerin kısıtlandığı dikta yönetimleri değil, ortak akılla ve kamuoyunun katılımılla özgürlüklerden taviz vermeden onuruyla yaşanabilecek adil bir yönetim şekline işaret etmiştir ${ }^{129}$. İslam dini, tevhid inanclnın eşitlik anlayışından dolayı, ister dini ve mezhebi, ister etnik ve ideolojik olsun, özgür yaşamı yok ettiği için, her türlü dikta yönetiminin karşısındadır ${ }^{130}$.

123 Hud, 11/61.

124 Maide, 5/8.

125 Hucurat, 49/13, 11.

126 En'am, 6/57; Yusuf, 12/40, 67.

127 Maide, 5/120, 17; Bakara, 2/107.

128 Kasas, 28/77.

129 Nisa, 4/59.

130 Hucurat, 49/13. 
Tarih boyunca insanın ihtiyaç duyduğu en önemli duygulardan biri, kendini güvende hissetmesidir. Fıtrat itibariyle insan, yaşamını tehlikeye atacak durumlardan olabildiğince kaçar, buna imkân bulamazsa ölümüne, o tehlikeye karşı koymaya çalışır. Bunun için diğer canlılardan farklı olarak insan anne kucağı, aile ocağı ve devlet mekanizması gibi güvenlik yapılanmalarına ihtiyaç duyar. Eğer insan, kendisini güvende hissetmezse her türlü köleliği kabul eder. Hatta bazen kendi özünden bir parçaymış gibi köleliğe sarıı. Dahası, bazen bedenini kurtarmak için ruhunu bile esir verebilir. Bu sebeple, çeşitli tabulara inanıp kendini tuhaf korkuların esiri haline getirebilir. Halbuki tevhid inancına sahip olmak, insanı, birçok korku ve bağımlılıktan kurtarır. Başka bir ifadeyle mutlak güce iman, insana, belli bağımlılıklardan kurtulmak ve onlara karşı gelmek için büyük bir cesaret verir. Çünkü iyilik, cesaret ve güvenin kaynağında iman; kötülük, korkaklık ve güvensizliğin kökeninde ise inançsızlık yatar. Zira insan, emelleri sonsuz, sermayesi az; düşmanları çok, gücü ise sınırlı bir varlıktır. Bu durumda o, ancak her şeye gücü yeten ve her şeyin anahtarı yanında olan bir varlığa dayanmakla kendini güvende hisseder ve varlığını devam ettirir. Bu açıdan hakiki özgürlük Allah'a kullukta, kölelik ise O'nu tanımamaktadır, denilebilir. Çünkü Allah'a iman eden kişi, tüm siyasi ve otoriter güçlere karşı kendini güvende hisseder ve özgür yaşar. Zira tevhid inancı, insanı özgürleştiren en etkin araçtır ${ }^{131}$.

İslam'a göre insanı diğer varlıklardan ayıran ve onu en iyi tanımlayan kavram özgürlüktür. Zaten hürriyet yoksa insan da yoktur. Ancak güvenlik yoksa özgürlükten de söz edilemez. İslam'da, güvenlik ve özgürlüğün birbirine karşıt kavramlar olduğu söylenemez. Bununla beraber tevhid inancının ana kaynağı Kur'an'a bakıldığında, birey-devlet ilişkisinin konu edindiği görülür. Fakat devlet karşısında bireyin hak ve özgürlüklerinden ayrıca bahsedilmez. Bu yönüyle diyebiliriz ki, İslam'da, siyasal manada değil, dinî-ahlakî manada meşruluk ve özgürlük fikri ön plana çıkmıştır. Bu çerçevede bireysel özgürlük, hayatın temeli kıvamında bir imtihan süreci, dolayısıyla insanın varoluş amacı olarak tanımlanmıştır. Onun için İslam'da siyasal iktidar, bu temeli yıkarak ve kişi hürriyetinin varoluş alanını işgal ederek değil, kendini öncelikle hukukla ve sonra toplumun maslahatıyla kayıtlayarak $^{132}$ var edebilir. Dolaysıyla tevhid inancının bir gereği olarak kişi, ne tüm haklarını herhangi bir siyasal otoriteye teslim eder, ne de herhangi bir siyasal güç bireyin tüm hak ve özgürlüğünü vesayet altına alabilir.

131 Bu durum Kur'an'da şöyle ifade edilmiştir: "Dinde zorlama yoktur. Artık doğrulukla eğrilik birbirinden ayrılmıştır. O halde kim tağutu reddedip Allah'a inanırsa, kopmayan sağlam bir kulpa yapışmıştır. Allah işitir ve bilir". (Bakara, 2/256).

132 Bu esas, Mecelle'de "Raiyye (tebaa) üzerinde tasarruf, maslahata menuttur." (Mecelle, md. 58.) şeklinde ifade edilmiştir. 


\subsection{Hukuk-Özgürlük İlişkisi}

Hukuk kavramı "hak" kelimesinden türemiştir. Hukuk, Müslümanlarda fıkıh kavramıyla ifade edilmiştir. Bu kelime sözlükte, "bir şeyi bilmek, iyi ve tam anlamak, derinlemesine kavramak" manasına gelir. Terim olarak ise, kişinin lehinde ve aleyhinde olanı bilmesi olarak tarif edilmiştir ${ }^{133}$. Hukuk toplum ve devletin hareketlerini, birey ile devlet ilişkilerini düzenleyen, yetkili organlar tarafından usulüne uygun olarak çıkarılan, kamu gücüyle desteklenen, muhatabına nasıl davranması gerektiğini gösteren ve bunun için ilgili yasaları tanzim eden normatif bir bilimdir ${ }^{134}$. Başka bir ifadeyle, toplumu düzen altına alan ve kişiler arası ilişkileri düzenleyen, ortak yaşamın huzur ve güven içinde akışını sağlayan, adaleti sağlamak için gerektiğinde devletin gücünü kullanan ve siyasi otorite tarafından yaptırımlarla güvence altına alınan kurallar bütünüdür. Hukuk sisteminde bütün insanların eşit olması, özgürlüğün sınırsız kabul edilmesi, hukukun yönetim erkinden bağımsız olması ve hiç kimsenin kendi davasının yargıcı olmaması gibi ilkeler, insan özgürlüğünün güvence altına alınması için kabul edilen önemli unsurlardır.

İslam hukukunun temel kaynağı Kur'an-ı Kerim'dir. Bu hukukun, esasta vahye dayanmakta oluşu, onun en önemli karakterini oluşturur. Gerek Hz. Peygamber'in sünneti gerekse diğer âlimlerin içtihatlarına dayanan fıkıh da ilham ve ölçüsünü vahiyden alır. Diğer hukuk sistemlerinde, hukukî ve cezaî müeyyidelerin etki alanı dünya hayatı ile sınırlı iken, İslam hukukunda müeyyideler ebedi hayatı da kapsamaktadır. Ayrıca, bu hukukta, dünyevî ve maddî müeyyidenin yanında sevap ve günah telakkisinin olması, kanuna itaatin aynı zamanda bir iman ve kulluk vazifesi olarak algılanması, vicdanların eğitilmesinde önemli bir etki bırakmaktadır. Onun için İslam hukukunda kanun koyucu, Yüce Yaratıcı́nın kendisidir. İnsanın yetkisi ise ancak ilahi hükümleri araştırıp bulmak ve keşfetmektir. Zira içtihat, beşerin kendinden hüküm koyması değil, ilahi hükmü bulup ortaya çıkarması anlamına gelmektedir. Onun için müçtehidin içtihadı, kendisini bağlamakla birlikte, devlet ve yetkili merciler için hükümleri belirlemede ancak bir kaynak teşkil etmektedir ${ }^{135}$.

Insanlık tarihi boyunca bireyin irade ve seçiminin, kültürel değerler ve çevresel faktörlerden etkilendiği şüphesizdir. Bunların tesirini kırmak için birey, kendi ye-

133 Saffet Köse, İslam Hukukuna Giriş, (İstanbul: Hikmetevi Yayınları, 2018), 19.

134 Turgut Akıntürk, Hukuka Giriş, (Eskişehir: Anadolu Üniversitesi Yayınları, 2002), 3.

135 Hayreddin Karaman, "FIkıh", İslam Ansiklopedisi, XIII, 1-14. 
tenek, akıl ve bilgisine güvenmesinin yanı sıra yasaların güvencesi de gerekir. Yasalar, bireyi körü körüne itaatten ve başkalarının etkisi altına girmekten korur. Kişinin, kendini gerçekleştirmek için kendi yetenek ve çabasının yanında, çoğu zaman yasaların güvencesi de gerekir. Özgürlüğün temel dayanağı, bireyin kendi varlığı, yapıp etmeleri, başarı ve yetenekleriyle beraber belli birtakım yasaların mevcudiyetidir. İşte bu yüzden, başkasının etkisinden uzak bireysel özgürlüklerin, yasaların güvencesi altında olması gerekir. Ancak bu şekilde birey, özgürleş(tiril)ebilir ve dolayısıyla özünü bulabilir. Çünkü hukuk, özgürleş(tir)menin ön koşuludur. Hukukun üstünlüğü ve bireye tanıdığı koruma sayesinde kişiler yeteneklerini ortaya koyma imkânını bulabilir. Böylece bireye yön veren, düşünce ve davranışlarını belirleyen otoritenin yerini yasa almış, itaatin karşısına kurallar çıkmış ve sonuçta inanç ve aklın sınırları belirlenmiş olur. Sonuç olarak diyebiliriz ki, bireyin özgür olması, özgürlüğün hukuk çerçevesinde güvence altına alınmasıyla mümkün olur.

İslam'a göre bireyin dinî veya ahlâkî sorumluluklarını yerine getirmesi, ötekinin özgürlük ve temel haklarına dokunmadıkça, tamamen kendi seçim ve vicdanına bağlıdır. Ayrıca İslam'da günah ve suçlarda esas olan, cezalarının ahirete kalmasıdır. İslam fıkhında ukubat ${ }^{136}$ bölümünün olması ve suç olarak tanımlanan fiillere dünyevî yaptırımların belirlenmesinde temel amaç, bu fiillerin başkalarına zarar vermesini engellemektir ${ }^{137}$. Diğer bir deyişle, hukukun vazedilme nedeni ve ahlaki gelişimin metodu, bireysel iradeyi zayıflatmak değil, bilakis kuvvetlendirmektir. Zaten özgürlüğün kendisi, bir varoluş sebebidir. İslam, insana bu alandaki siyasal iktidar ve toplumun, gelenek ve alışkanlıkların, içgüdü ve önyargıların oluşturduğu örgüleri gösterip hudutlarını çizer. Ancak asıl sınırları, bizzat sorumluluğu yüklenen insanın akıl ve vicdanına dayanan sorumluluk bilincinde oluşturur. Bu sebepten ötürü tevhid dini olan İslam'da zorlama yoktur ${ }^{138}$, aksine özgürlük ve serbestlik vardır. Zira hayat, özgürlükle kaimdir. Çünkü varlıkta hayat kalitesinin seviyesi yükseldikçe, özgürlük de nitelik olarak yükselir. Bitkilerden

136 Ukubat kelimesi, sözlükte, bir şeyin bedeli ve karşılığı, iyi veya kötü olan bir fiil ve davranışın tam ve yeterli karşılığını vermek anlamına gelir. İslam literatüründe bu kavram, genel anlamda dünyevî veya uhrevî mahiyette özendirici veya caydırıcı müeyyideden ibarettir. Özel anlamda ise dünyada hukuk düzeni tarafından suçluya uygulanacak maddî ve manevî müeyyideyi ifade eder. (Adil Bebek, "Ukubat", İslam Ansiklopedisi, VII, 469-470.

137 Burhanüddin Ebu'l-Hasan Ali el-Merginanî, el-Hidaye Tercemesi, trc. Ahmed Meylanî, (İstanbul: Yasin Yayınevi, 1986), II, 327.

138 Bakara, 2/256. 
insana doğru yükselen varlık basamaklarında özgürlük de hayatın kalitesindeki yükselişe eşlik eder. Zaten İslam, özgürlüğün bir hak olduğuna değinmeden önce onun, fitrî bir vaka olduğunu tespit eder. Bununla ilgili Hz. Peygamber'in, Allah'ın, hakkında sükût ettiği şeylerden insanların muaf olduğunu belirtmesi ${ }^{139}$, fıkıhta: "Aslolan serbestliktir (ibaha)" şeklinde ifadesini bulmuştur. Netice olarak, tevhid dini İslam'da hukuk önünde herkesin eşit kabul edilmesi, emredilen ve yasaklanan kuralların dışında kalan her şeyin insan seçimine bırakılmış olması, kişi özgürlüğünün esas alındığının açık bir delilidir.

\subsection{Toplumsal Değerler-Özgürlük ilişskisi}

Toplumsal değerler, bir toplumda süreklilik arz eden örf, adet, gelenek, görenek ve töre gibi yazılı olmayan kurallar bütünüdür ${ }^{140}$. Bu değerler, toplumun geçmişten getirip üzerine ekleme yaparak devam ettirdiği düşünce ve davranış kalıplarıdır. Bunlar, hem toplumun varoluş sebebidir hem de geleceğini inşa eder ${ }^{141}$. Bu değerlerin önemi, sosyal hayatın dünü, bugünü ve yarınını kuşatan bir kapasiteye sahip olmasından kaynaklanır: Toplumda birlik, güven ve dayanışma bu değerler sayesinde sağlanır. Ancak bütün bunlara rağmen, sosyal değerler, bazen insanın serbestçe düşünmesini, özgürlüğünü ve icatçı yönünü olumsuz etkileyerek, adeta onun irade, idrak ve benliğini esir alır ${ }^{142}$. Tabi burada toplumsal değerlere körü körüne bağlılık ${ }^{143}$ gibi onları bir bütün olarak reddetmek de doğru bir özgürlük anlayışı değildir. Bu noktada geçmişin mirasından doğru ve sağlam olanları alarak günümüze ve geleceğe taşımak ve onları sürekli hale getirmek en doğru yol olsa gerektir ${ }^{144}$. Geçmişten getirilen değerleri kutsayıp onlara körü körüne bağlanmanın doğru olmadığını Kur'an şu şekilde ifade etmektedir: "Onlar gelip geçmiş bir ümmettir. Onların kazandıkları kendilerinin, sizin kazandıklarınız

139 Tirmizî, "Libas", 6.

140 Seyyid Hüseyin Nasr, İslam ve Modern İnsanın Çıkmazı, çev. Ali Ünal, (İstanbul: İnsan Yayınları, $1984,89$.

141 Şehmus Demir, "Geleneğin Ne'liği ve Değersel Boyutu Üzerine", Marife Dergisi, yıl:8, sayı:1, Bahar 2008, 191.

142 İbrahim Yıldız, "Kur'an-ı Kerim’de Atalar Geleneği ve İnanca Etkisi”, KSÜ Illahiyat Fakültesi Dergisi, yıl: 2015, 175-216.

143 Bakara, 2/170; Maide, 5/104.

144 Celalettin Vatandaş, Hz. Muhammed (s.a.s.)'in Hayatı ve İslam Daveti-Mekke Dönemi, (İstanbul: Pınar Yayınları, 2012), 284. 
sizindir. Siz onların yaptıklarınızdan sorumlu tutulacak değilsiniz"145. Bu ayette ifade edildiği gibi sosyal âdetleri körü körüne devam ettirmek yerine onların doğrularını yanlışlarından ayırarak devam ettirmek gerekir. Bu da ancak Yüce Allah'ın gösterdiği tevhid merkezli hak dinin ölçüleri esas alınarak yapılabilir.

Kur'an-ı Kerim, toplumsal değerlerin, bireyi kuşatıp düşünce ve davranışlarını etki altına aldığı gerçeğini kabul etmekle beraber, tevhid merkezli vahyin ışığında ancak bu birikimin süzgeçten geçirilerek alınmasıyla kurtuluşa erişebileceğini ifade etmiş ${ }^{146}$ bir kitaptır. Diğer bir deyişle kişinin, özgürlüğünü yok edecek derecede mevcut inanç ve kültürel değerleri olduğu gibi taklit değil ${ }^{147}$, onları akıl ve bilimin süzgecinden geçirip tahkik ederek benimsemesi gerekir. ${ }^{148}$ Çünkü onlar, bazen insanın benliğini ve iradesini esir alacak şekilde bir baskı ortamı oluşturabilir. Bunun için Kur'an'da insan iradesini sınırlayan sosyal baskının etkisine karşı birey şu şekilde uyarılmaktadır:"Allah yolunda cihat ederler, hiçbir kınayıcının kınamasından korkmazlar."149. Bu ayette de ifade edildiği gibi çoğu zaman insanın, çoğunluğa uyma isteği, çoğunluğun beğenisini kazanma arzusu veya dışlanma korkusu olabilir. İşte bu ayet, toplumdaki bu beklenti ve korkulara kapılmadan, kınayıcıların da kınamasından korkmadan özgür bir şekilde hareket etmek gerektiğini ifade etmiştir.

İslam'da bireysel özgürlük anlayışının toplumsal alana yansıması, bireyin vesayet altına alınmadan, kendi eylemlerinin sonuçlarını üstlendiği ve özgürlüğünün bütün boyutlarıyla güvence altına alındığı bir yapı akla gelir. İnsanın gerçek özgürlüğü, kendi özgürlüğü ve toplumsallığı arasındaki dengeyi gözettiğinde anlam kazanır. Meseleyi biraz daha açmak gerekirse özgürlük, insanın toplumla ilişkilerinde gündeme gelen sosyal bir kavram olduğu için onun güvenceye alınması ancak sınırlandırılmasıyla mümkün olur. Aslında bireysel özgürlüğe ilişkin yapılmış her sınırlandırma, onu güvence altına alma amacıyla yapılmıştır. Bu yönüyle sınırlandırma, söz konusu özgürlüğün güvenceye kavuştuğu sınır çizgisidir diyebiliriz. Çünkü kişi başkalarına tanıdığı özgürlük sınırının ötesinde kendini özgürleştiremez. Diğer bir ifadeyle kişi, kendi düşünce ve eylemlerini özgürleştirebildiği nispette başkalarının eylem ve davranışlarına özgürlük kazandırabilir. Sonuç olarak diyebiliriz ki, başkasının özgürlüğüne ne kadar imkan tanırsak, kendimiz de o kadar özgür oluruz.

147 Bur durum Kur'an'ın bir ayetinde şöyle ifade edilmektedir: "Onlara, 'Allah'ın indirdiğine ve Resul'e gelin' denildiği vakit, 'babalarımızı üzerinde bulduğumuz (yol) bize yeter' derler. Ataları hiçbir şey bilmiyor ve doğru yol üzerinde bulunmuyor iseler de mi?". (Maide, 5/104).

148 Ebu Mansur Muhammed el-Maturidî, Kitabu't-Tevhîd, nşr. Fethullah Huleyf, (Beyrut: 1970), 3. 
İslam'ın temel amaçlarından biri tevhid merkezli, adalet ve özgürlük esaslarına dayalı bir toplum kurmaktır. Bu sebeple dinde zorlama olmadığı, insanlara verilen özgürlüğün geri alınamayacağı, mezhep ve inanç alanında sürekli bir ihtilafın ihtimal dâhilinde olduğu ${ }^{150}$ vurgusu yapılmıştır. Buna göre, Müslümanların önünde ikna metoduna dayanma, kültür ve inanç farklılığıyla birlikte her insana yaşam güvencesi verme konusunda adil bir toplum tesis etmekten başka bir yol yoktur $^{151}$. Dolayısıyla Müslümanlara, ne ötekinin zihin ve vicdanına hükmetme hakkı ne de mutlak anlamda bireysel otonomi ve sorumluluğu üstlenme yetkisi verilmiştir. Çünkü dinî açıdan insan, hak-ödev bütünlüğü içinde kalarak sorumluluk duygusuyla hareket etmek zorundadır. Zira tevhid dininin ana kaynağı Kur'an'da vurgulanan, insanın varoluş gayesi ve buna eşlik eden bireysel sorumluluk, kişinin, kendi isteğiyle özgürlüğünden vazgeçmesine izin vermemektedir. İnsan, ne bireysel sorumluluğunu ne de bu sorumluluğun önkoşulu olan özgürlüğünü bir başka yer ve makama devredemez. Aklını ve özgürlüğünü kullanmayı bırakıp başka birilerinin anlayış veya inançlarına teslim olması, akıl ve özgürlüğünü bir kitle hareketine ya da kitle lider(ler)ine bırakması kabul edilemez. Böyle herhangi bir durum, onun sorumluluğunu asla ortadan kaldırmaz. Kur'an'a göre, sadece insanları, nüfuz altına alan, zihinlerini şartlandıran ve doğru yoldan uzaklaştıranlar değil, onlara iradelerini teslim edenler de sorumludur ${ }^{152}$. Çünkü insanın, isteyerek aklını ve iradesini başka bir yere devretmesi, onun bireysel sorumluluğunu asla ortadan kaldırmaz. Üstelik İslam’a göre kişinin, güçsüz ve zayıf olma durumu da bu konuda geçerli bir özür olarak kabul edilmemiştir ${ }^{153}$.

Ontolojik açıdan insan özgürlüğü, potansiyel olarak kötülüğü barındırdığı veya kötülüğe bizzat sebep olduğu halde, ahlâkî değer ve doğru olanı gerçekleştirmenin önemli bir ön şartı olarak kabul edilmiştir. Çünkü özgürlüğün, gerçekleştireceği değere nispeten, bu riskin varlığı, arızî ve cüz'îdir. Zaten bu riskin olmaması durumunda insanın varlık nedeni tartışmalı hale gelir veya bu riski almak istemeyen insan, özgürlüğünü devredecek kişi ve kurumlar aramaya başlar ${ }^{154}$. Bu yüzden Kur'an, bireysel sorumluluğa vurgu yaparak, ondan kaçışın sorumluluk gerektireceğini bir ayette şöyle dile getirmiştir: "Artık kim doğru yolu seçerse kendi

150 Hud, 11/118-119; Yunus 10/19; Bakara 2/253.

151 Raşid el-Ğannûşî, Hukûku'l-Muvâtanah: Hukûku Ğayri'l-Müslimîn fî'l-Mücteme'ı'l-islâmî, (Virginia: 1992), 55.

152 Arâf 7/172-173.

153 Mü'min, 40/47-48.

154 Şaban Ali Düzgün, Sosyal Teoloji -Insanın Yeryüzü Serüveni-, (Ankara: Çağrı Yayınları, 1999), 65. 
lehinedir. Kim de saparsa ancak kendi aleyhine sapmış olur. Sen onların üzerinde vekil değilsin"155. Bu ayette ifade edildiği gibi insan, yaptıklarından birey olarak sorumlu olduğu gibi karşılığını da tek başına birey olarak görecektir. Ayrıca Kur'an'a göre insanlar, ahiret hayatında, tek tek bireysel olarak sorgulanacaktır ${ }^{156}$. Bu yüzden İslam, taklit yoluyla inanmaya, bir kısım lider veya kitle hareketlerine iradeyi teslim etmeye ve toplum içinde öz benliğini eritmeye olumsuz bakmış bir dindir.

\subsection{Ekonomi-Özgürlük iliş̧kisi}

İslam'da ekonomi, insan ile insan veya insan ile diğer varlıklar arasındaki ilişkileri düzenleyen muamelat konularından biridir. Muamelatın esas ve ilkeleri Yüce Allah, teferruatı ise intiyaç, menfaat, hak ve adalet ışığında insanlar tarafından belirlenmiştir. Ekonomi, bir insan faaliyeti ve insan eylemlerinin sonucu ortaya çıkan bir durum olmakla beraber, onun sınır ve meşruiyet kriterlerini tevhid dini İslam belirlemiştir. Yani ekonomi, esasları itibariyle dini kaynaklara ve dini pratiklere dayanmamaktadır. Dolayısıyla İslam'da insan, ekonomi konusunda mutlak anlamda hür değildir. O, ekonomiyle ilgili faaliyetlerinde Allah'ın koyduğu sınırlara uymak zorundadır. Başka bir ifadeyle insan ne üretim ne de tüketim alanında kafasına buyruk kayıtsız ve şartsız özgür değildir. İslam, insanın hem üretim hem de tüketimine belli sınırlar koyarak, hareket alanını belirlemiştir. Ayrıca ekonominin özü olan kazancı, emeğe dayalı hale getirmiştir. Yani ekonominin temeline emeği koyarak ona kutsal bir değer biçmiş ${ }^{157}$ ve bu yolla emeğin sömürülmesini de engellemiştir ${ }^{158}$. Mesela ekonomik alanda faiz ${ }^{159}$ ve gararı $^{160}$, kumar $^{161}$

155 Zümmer, 39/41.

156 Meryem, 19/95.

157 Necm, 53/39.

158 Ahkaf, 46/19; Buharî, "İcare”, 12, 15; Müslim, "İman” 38, 40.

159 Türkçe'deki yaygın karşılığı "faiz" olan Arapça riba kelimesi sözlükte "fazlalık, nema, artma, çoğalma, yükseğe çıkma, serpilip gelişme" gibi anlamlara gelir. Fıkıh literatüründe ise riba, borç verilen bir para veya malı belli bir süre sonunda belirli bir fazlalıkla yahut borç ilişkisinden doğan ve süresinde ödenmeyen bir alacağa ek vade tanıyıp bu süreye karşılık onu fazlalıkla geri almanın veya bu şekilde alınan fazlalığın adıdır. (İsmail Özsöy, "Faiz", İslam Ansiklopedisi, XXII, 110-126).

160 Garar, sözlükte "tehlike, risk, kişinin bilmeden canını veya malını tehlikeye sokması" gibi anlamlara gelir. Terim olarak ise, risk almadan para kazanmaktır. Garar yasağının temelinde haksız kazancın önlenmesi fikrinin bulunduğu ve sözlük anlamı itibariyle de gararın aldanma veya aldatma gerçeğiyle bağlantılı olduğu söz konusudur. (İbrahim Kâfi Dönmez, "Garar”, İslam Ansiklopedisi, XXIII, 366-371).

Maide, 5/90-91. 
ve aldatmayı yasaklamış ${ }^{162}$, belli miktardaki malı ${ }^{163}$ zenginlerden alarak fakirlere zekât ${ }^{164}$ olarak vermeyi zorunlu kılmıştır. Faiz ve gararın yasaklanması ile çalışmadan para kazanma, işletilmeyen paradan zekât alınması ile de paranın durağan olması engellenmiş, böylece yatırım teşvik edilmiştir. Bu sayede Müslümanlar, tevhid merkezli ahlak, adalet, akıl ve hukuk çerçevesinde bir ekonomi modeli içinde hayat sürdürmeye yönlendirilmiştir.

Daha önce belirttiğimiz gibi İslam, tevhid merkezli bir dindir. Önerdiği ekonomi sistemi, tevhid eksenlidir. Mal mülk mutlak anlamda Yüce Allah'ındır ${ }^{165}$. İnsanın onlara sahiplenmesi de nispi ve görecelidir ${ }^{166}$. Insan ne üretimde ne de tüketimde mutlak anlamda özgür değildir ${ }^{167}$. Bu yüzden İslami ekonomik düzen, ne kapitalist ne de sosyalist sistemlerle eşdeğer kabul edilmiştir. Sosyalist düzende, insan herhangi bir özel mülkiyete sahip değilken, kapitalist sistemde, mutlak anlamda her şeyin sahibidir. İslami ekonomi ise, her iki sistemin negatif özelliklerini revize eden üçüncü bir yoldur. Örnek verecek olursak İslami ekonomide üretim ve tüketim araçlarında özel mülkiyet hakkı vardır. Kişisel kazanç ve teşebbüs hürriyetinin teşvik edildiği serbest piyasa ekonomisi egemendir. Belli sınırlar içerisinde ticaret yapmak serbesttir. Yapılan işe ve sahip olunan beceriye göre serbest piyasa şartlarında karşılıklı rızayla ücret tahakkuk eder. Ancak Kur'an'da ifade edilen: "Muhakkak ki, müminler kardeştir"168 gibi ilkelerle rekabet etmenin sınırları belirlenmiştir. Ayrıca sosyalist ve kapitalist sistemler, insan ürünü, materyalist, hazcı ve belli sınıflara mahsus birer düzen iken, İslamî ekonominin usul ve esası, Kur'an- Kerim ve onun açıklayıcısı Hz. Peygamber'in Sünnet'i tarafından belirlenmiş tevhid eksenli, manevî, bütün sınıflara hitap eden, insan fıtratına ve tabiat kanunlarına uygun bir sistemdir ${ }^{169}$. Bunun için orta tabakaya mensup bir aileden gelen Hz. Peygamber'in tebliğ ettiği İslam'ın müntesiplerinin sosyal sınıf ve çevresi, diğer dinlerden farklıdır. İslam'ı kabul edenler her sosyal sınıftan kişi-

162 Mutaffifin, 83/1-6.

163 İslam hukukunda kişinin zenginlik ölçüsü olarak kullanılan terim nisab kelimesidir. Nisab, Sözlükte "sınır, işaret, asıl, kök, kaynak" gibi manalara gelir. Fıkıh terimi olarak ise zekâtın farz olduğunu gösteren zenginlik ölçüsü anlamına gelir. (Mehmet Erkal, "Nisab”, İslam Ansiklopedisi, XXXIII, 138-140).

164 Bakara, 2/3.

165 Mümin, 40/16.

166 Tevbe, 9/111.

167 A'raf, 7/31.

168 Hucurat, 48/10.

169 Faruki, Tevhid, 223-229. 
ler olmuştur. Bu yönüyle tevhid eksenli İslam'ın ne kapitalizm gibi aristokratlara ne de sosyalizm gibi sosyo-ekonomik durumu düşük alt sınıflara dayandığı iddia edilemez. Tevhid inancının bir gereği olarak bütün insanları eşit gördüğünden ötürü İslam dini, ekonomik açıdan her sosyal tabakadan müntesip bulabilmiştir.

\subsection{Fiziki Varlıklar-Özgülük İlişkisi}

İslam'a göre insan fıtratı temizdir. Onun mahiyetinde, Allah'ın varlığına ve birliğine inanma ve O'na ibadet etme duygusu vardır. Ancak bazen hakkı ararken batıla denk gelir ve onu hak diye sahiplenmeye çalışır. Yani bazen yanlış bilgi ve yorumlardan dolayı yanlış inanç ve ibadet şekillerine kapılır. Ayrıca insan bazen de karşılaştığı etkileyici ve gizemli olayların sebeplerini izah edemediğinden onları manevi güçlere bağlayarak anlamaya çalışır ${ }^{170}$. Şöyle ki, kendilerinden yardım istemek veya birtakım korkularını gidermek için bir kısım nesnelere olağanüstü güçler atfederek onları ilahlaştııır. Zira bir nesneden menfaat görmek ve onu aşırı sevmek veya onun zararını bertaraf etmek ve ondan aşırı korkmak, insanı Allah'ın iradesi dışında bir davranışa sürükleyebilir. Bunun için insan, zaman zaman Yüce Allah'ın yaratmak, verimli kılmak ve kemale erdirmek gibi sıfatlarını Güneş, Ay, rüzgar, yağmur, tabiat veya doğayı verimli kılmak üzere kullanılan bir nesneye atfederek onları ilahlaştırmıştır. Bundan dolayı tarih boyunca Yüce Allah, sayısız peygamber göndererek, insanların edindiği bu batıl inancı yok ederek onları tevhid inancına yönlendirmeye çalışmıştır. Bu durum Kur'an'ın şu ayetinde şöyle ifade edilmiştir: "Onlar, 'Seni eksikliklerden uzak tutarız. Seni bırakıp da başka dostlar edinmek bize yaraşmaz. Fakat sen onlara ve atalarına o kadar bol nimet verdin ki, sonunda seni anmayı unuttular ve helake giden bir toplum oldular' derler"171. Başka bir ayette ise: "Gece ve gündüz, güneş ve ay O'nun ayetlerindendir. Eğer gerçekten Allah'a tapıyorsanız güneşe ve aya secde etmeyin. Çünkü onları yaratan Allah'ıı'ı172 şeklinde ifade edilerek Allah'ın dışındaki fiziki varlıklara verilen ilahlık reddedilmiştir. Bu ayetlerde belirtildiği üzere insanın, bazen irade ve özgürlüğünü yanlış yönlendirdiği, Allah'ın dışındaki birtakım sahte varlıkları ilah edindiği ve dolayısıyla kendi değerini düşürdüğü dile getirilip eleştirilmiştir.

170 Muhammed Abay, Kur'an Kıssaları, (İstanbul: Ensar Neşriyat, 2007), 28.

171 Furkan, 25/18.

172 Fussilet, 41/37. 
Sonuç olarak diyebiliriz ki, insanın, kendi dışındaki varlıkları ilah edinmesi, insandaki sevgi, saygı, hürmet, tazim, korku ve endişenin aşırıya kaçması sonucu oluşur. Ancak İslam, insanın hem iman hem de amel noktasında tevhid inancına sahip olmasını ister. Başka bir ifadeyle İslam dini, insanın duasıyla, secdesiyle, ibadetiyle sadece Allah'a yönelmesini salık vermiştir. Zira aksini yapmak ise, şirk olarak kabul edilmiştir. Şirk ise büyük bir zulümdür ${ }^{173}$. Aslında şirk, insan iradesini istikametten ayırarak, onu, aslî görev ve rotasından saptırmaktır ki, o da İslam’ın tevhid inancına aykırıdır. Onun için İslam'da Yüce Allah'ın sevgisine ve korkusuna rağmen herhangi bir varlığa aşırı derecede tazim göstermek ve onlardan korkmak, insan özgürlüğüne aykırı bulunmuştur ${ }^{174}$.

\section{Sonuç}

İslam, Yüce Allah'ın insanlığa gönderdiği son ilahi dindir. Bu dine göre varlık temelde ikiye ayrılmaktadır. Bunlardan ilki, irade ve kudreti sonsuz ve zorunlu olan Yüce Yaratıcı'dır. İkincisi ise kendi başına var olamayan ve varlığını devam ettiremeyen ve dolayısıyla zorunlu varlığa bağlı olan mümkün varlıklardır. Mümkün varlıklar içerisinde irade ve ihtiyarı olan somut yegâne varlık insanoğludur. Onun için insanın, Yüce Yaratıcı'yla, kendisiyle ve diğer varlıklarla bilinçli bir etkileşimi söz konusudur. Bu etkileşim, bizzat kendi hür iradesiyle gerçekleşir ki, buna da "insan özgürlüğü" denir. Zira özgürlük, kişinin, kendi inanç, fikir ve davranışlarını her hangi bir zorlama olmadan veya her hangi bir engelle karşılaşmadan belirlemesi ve yaşamasıdır.

İslam'a göre, insan özgürlüğünün ilişkili olduğu temel ilkelerden biri, tevhid inancıdır. Müslüman kültüründe özgürlük, hürriyet kavramıyla ifade edilmiş ve çoğunlukla kölelik, determinizm ve fatalizmin karşıtı olarak kullanılmıştır. Genel olarak Müslümanlar, insan eylemlerinin seçimini insana, yaratmasını ise Allah'a havale etmişlerdir. Yani insan davranışları, yaratma bakımından Allah'a, kesp ve karar bakımından ise kişiye nispet edilmiştir. Bu yüzden insan davranışlarında etkin olan iki iradeden bahsedilmiştir. Böylece fiiller, sonuçları bakımından ilahi iradeye, seçim ve sebepleri açısından ise insan isteğine dayandırılmıştır. Ancak fiillerdeki bu ortaklık, insan sorumluluğunu asla ortadan kaldırmış olamaz. Bununla beraber insan, iradesi ve gücü ile onun eylemleri arasındaki ilişki, "mutlak

173 Lokman, 31/13.

174 Al-i İmran, 3/175. 
sebeplilik" prensibi kaynaklı değil, "iktiran" ilkesi çerçevesinde gerçekleşir. Şöyle ki, sebep-sonuç arasında gerçek illiyet değil, ardardalık münasebeti vardır. Yani sebepler, sonuçlar için mutlak anlamda olmazsa olmaz neden değil, sadece zamansal açıdan sebep ve sonucun birlikteliği söz konusudur. Bu yüzden Müslümanlar, Yüce Allah'ın, yegâne yaratıcı olduğunu ve iradesinin her şeyi kuşattığını ortaya koymak için insanın irade, güç ve hürriyetini asgari düzeye indirmeye çalışmışlardır. Onun için onlara göre insan, mutlak cebir altında bulunan diğer varlıklarla kıyaslandığında özgür bir varlık ise de mutlak irade ve güç sahibi olan Allah'a nispet edildiğinde ise cebir altındadır.

İslam'a göre insan, hem ontolojik olarak ayrıcalıklı hem de Allah'ın ona yüklediği görev ve sorumluluk açısından onurlu bir varlıktır. İnsanın değerli ve onurlu olması, onun özgür olmasını gerektirir. Zira ilahi irade karşısında özgürlük ve otonomiye sahip olmak onur, değer ve haysiyeti beraberinde getirirse de o, kimlik ve kişilik sahibi olmaya doğru gittikçe öz benliğini oluşturur ve kendi değerini kazanır. Bu süreçte kendi onurunun bilincine varması ve kişiliğini oluşturması ise özgürlüğe bağlıdır. Birey olarak kişi, kendini ve Yaratıcı'sını tanıdıkça ve çevreyle sağlıklı ilişki kurdukça benliği gelişerek açığa çıkar. Bu bakımdan, insanın kendini tanıması ve dolayısıyla kendini bizzat kendisinin inşa etmesi, Yaratıcı'sını bilmesi ve diğer varlıklarla doğru ilişki kurması, ancak özgürlüğü sayesinde olur.

İslam'da Allah, mutlak ve sorgulanamaz bir varlık iken, insanın sınırlı bir etkinlik alanı içinde sorumlu ve sorgulanabilir bir varlık olması, onun bir emanetçi konumunda olduğu anlamına gelir. Mülkün gerçek sahibi ve hâkimi olan Allah, doğrulukla idare etmek üzere, insana yeryüzünü imar etme sorumluluğunu yüklemiştir. Bu yüzden özgürlük, insanın, öncelikle Allah'tan başkasına kul olmaması ve nihayetinde içgüdü ve tutkularının güdümünden kurtulması demek ise de o, kendi Yaratııı'sına karşı istediği gibi davranma yetkisine sahip değildir. Onun için özgürlük denince akla ilk olarak insanın, Allah'a karşı görev ve sorumlulukları, daha sonra kendine ve diğer varlıklara karşı tutum ve davranışları gelir. Yani onun, başta Yüce Yaratıcı'ya, sonra kendisine, daha sonra ise tabiattaki bütün unsurlara karşı sorumluluğu söz konusudur. Bu yüzden o, ne nefsini ne de tabiatı istediği gibi kullanamaz. Ancak koruyup geliştirmek şartıyla onlardan istifade edebilir.

Sonuç olarak diyebiliriz ki, İslam dinine göre tevhid inancıyla insan özgürlüğü arasında önemli bir ilişki söz konusu ise de insan, bazen kendi duygularına (nefsânî güçlere) bazen de kendi dışındaki birtakım güçlere (din adamları, toplumsal 
değerler, iktidar sahipleri, putlar gibi) karşı hürriyetini koruyamamıştır. Ontolojik olarak doğuştan özgür olan insan, özgürlüğünü sonradan kaybedebilir veya kendi isteğiyle birilerine devredebilir. Böyle olunca insan bazen sözde bir hürriyet elde ettiğini düşünse de aslında içsel bir köleliğin (makam, para, şöhret, şehvet gibi) mahkumu olur. Bunun için insanın nefsânî ihtiraslardan kurtulması, içsel özgürlüğün ilk adımı olarak kabul edilmiştir. Zira gerçek sadece başkasına zarar vermemek demek değildir. İnsan, içten gelen bir özgürlükle desteklenmedikçe, nefsin istibdadına maruz kalır. Çünkü hürriyet, insanın, kendi içgüdülerine mahkum olması değil, gerektiğinde kendi kendine sınır koyabilmesidir. Yani insan ancak özgür bir birey olarak konumunu belirlerse eşref-i mahlûkat olabilir. Temel bir prensip olarak tevhid inancı, kişinin, Allah'tan başkasına kulluk yapmasını izin vermez. İslam'da "ihsan" ve "ihlas" kavramlarıyla ifade edilen bu prensibe göre, Yüce Allah'ı görürcesine O'na ibadet etmek (ihsan) ve hiçbir maddî ve manevî beklenti içine girmeden ibadetini sadece Allah'a mahsus kılmak (ihlas) her Müslümanın ulaşması gereken bir ruh halidir.

\section{Kaynakça}

Abay, Muhammed. Kur'an Kıssaları. İstanbul: Ensar Neşriyat, 2007.

Aclunî, İsmail b. Muhammed. Keşfu'l-Hafa. nşr. Ahmed el-Kalâş. Beyrut: yy, 1985.

Akoğlu, Muharrem. Mihne Sürecinde Mu'tezile. İstanbul: İz Yayıncılık, 2006.

Akseki, Ahmed Hamdi. Ahlak Dersleri. Ankara: Diyanet İşleri Başkanlığı Yayınları, 2016.

Akıntürk, Turgut. Hukuka Giriş. Eskişehir: Anadolu Üniversitesi Yayınları, 2002.

Ammara, Muhammed. Mu'tezile ve Devrim. trc. İbrahim Akbaba-İbrahim Güneş. İstanbul: Ekin Yayınları, 2000.

Ardoğan, Recep. "Kelamî Açıdan Birey-Siyasî Güç İkileminde Bireysel Özgürlük”. KSÜ Illahiyat Fakültesi Dergisi, 20 (2012): 1-38.

Aydın, Cüneyd-Genç, Ahmet. "Sünnetullah ve İnsanın İradesi Temelinde Kader". JOMELIPS 1/1 (Yaz 2016): 74-103.

Aydın, Mehmet S. Din Felsefesi. Ankara: Selçuk Yayınları, 1994.

Aydınlı, Osman. “Ilk Mustezileınin Özgür İrade Söylemi: Amr b. Ubeyd ve Kader Anlayışı”. Çorum Illahiyat Fakültesi Dergisi. 2002/2: 127-146.

Ayubi, Nazih. Arap Dünyasında Din ve Siyaset. trc. Yavuz Alogan. İstanbul: Varlık Yayınları, 1992.

Bağdâdi, Abdulkahir. Kitabu Usulu'd-Din. İstanbul: yy, 1928.

Batur, Muhammet Raşit. Zeydilik ve Selefilik Arasında Ibnü'l-Vezir. Ankara: Gece Akademi Yayınları, 2018.

Bebek, Adil. “Ceza”. İslam Ansiklopedisi, VII/469-470. İstanbul: TDV Yayınları, 1993

Cürcanî, Ali b. Muhammed eş-Şerif. et-Ta'rifat. thk. Muhammed Sıddîk el-Minşavî. Kahire: yy, 2004. 
Çağrıcı, Mustafa. İslam Düşüncesinde Ahlak. İstanbul: DEM Yayınları, 2012.

Çavuşoğlu, Raşit-Hamide Ulupınar. Bekir Sıdkı Visâlînin Sohbetleri. Ankara: Ilâhiyât Yayınları, 2020.

Çelebi, Kınalızade Ali. Ahlak-ı Alâî̀. haz. Mustafa Koç. İstanbul: Klasik Yayınları, 2007.

Demir, Şehmus. “Geleneğin Ne'liği ve Değersel Boyutu Üzerine”. Marife Dergisi, 8/1 (Bahar 2008): 189201.

Dönmez, İbrahim Kâfi. “Garar”, İslam Ansiklopedisi. XIII/366-371. İstanbul:TDV Yayınları, 1996.

Düzgün, Şaban Ali. Sosyal Teoloji-Insanın Yeryüzü Serüveni-. Ankara: Çağrı Yayınları, 1999.

Düzgün. “Varlık”. Kelam El Kitabı. Ankara: Grafiker Yayınları, 2015.

Erdem, Hüsameddin. Ahlak Felsefesi. Konya: Hü-Er Yayınları, 2009.

Erkal, Mehmet. "Nisab", İslam Ansiklopedisi. XXXIII/138-140. İstanbul: TDV Yayınları, 2007.

Farabî, Ebû Nasr. İdeal Devlet. çev. Ahmet Arslan. Ankara: Divan Kitap Yayınları, 2012.

Fazlur Rahman. Allahı́n Elçisi ve Mesajı -Makaleler I-. trc. A. Çiftçi. Ankara: Ankara Okulu Yayınları, 1997.

Faruki, İsmail Raci. Tevhid (Düşünce ve Hayata Yansımaları). İstanbul: Mahya Yayıncılık, 2017.

Gazalî, Ebû Hamid Muhammed. Ihyau Ulumu`d-Din. trc. Sıtkı Gülle. İstanbul: Huzur Yayın Dağııım, 1998.

Ğannûşî, Raşid. Hukûku'I-Muvâtanah: Hukûku Gaari'l-Müslimîn fi'l-Mücteme'I'l-Islâmî. Virginia: yy, 1992.

İbn Miskeveyh, Ahmed b. Muhammed. Tehzibu'I-Ahlak (Ahlak Eğitimi). İstanbul: Büyüyenay Yayınları, 2013.

Ikbal, Muhammad. The Reconstruction of Religious Thought in Islam. Lahore: yy, 1989.

İsfahanî, Rağıb. Müfredat. çev. Yusuf Türker. İstanbul: Pınar Yayınları, 2002.

Jaspers, Karl. Felsefe Nedir? trc. İ. Zeki Eyuboğlu. İstanbul: Say Yayınları, 1986.

Karaman, Hayreddin. “Fıkıh". İslam Ansiklopedisi XIII/1-14. İstanbul: TDV Yayınları, 1996.

Kaya, Mustafa. "Feyerabend'de Bilim ve Özgürlük İlişkisi". Eğitim ve Sosyal Bilimlerde Yeni Araştırmalar. Ankara: Berkan Yayınevi, 2019.

Kazerunî, Alaüddin. Şerhu'I-Ahlaki'l-Adudiyye. İstanbul: Türkiye Yazma Eserler Kurumu Başkanlığı Yayınları, 2014.

Kutlu, Sönmez. "Ehl-i Sünnet Siyaset Anlayışının Dinî Temellerinin Sorgulanması”, e-Makalat Mezhep Araştırmaları, 1/1, (Bahar 2008): 7-26.

Köse, Saffet. İslam Hukukuna Giriş. İstanbul: Hikmetevi Yayınları, 2018.

Lewis, Bernard. Islâm’ın Siyasal Dili. trc. Fatih Taşar. Kayseri: Rey Yayınları, 1992.

Mâtürîdî, Ebu Mansur Muhammed. Kitabu't-Tevhîd. nşr. Fethullah Huleyf. Beyrut: yy, 1970.

Mâtürîdî. İslam İnanç Esasları (Fıkh-ı Ekber Şerhi). çev. Adnan Bülent Baloğlu-Murat Memiş. Ankara: İsveç Diyanet Vakfı, 2013.

Merginanî, Burhanüddin Ebu'l-Hasan Ali. el-Hidaye Tercemesi. trc. Ahmed Meylanî. İstanbul: Yasin Yayınevi, 1986.

Nasr, Seyyid Hüseyin. İslam ve Modern İnsanın Çıkmazı. çev. Ali Ünal. İstanbul: İnsan Yayınları, 1984.

Nesefí, Ebu'I Muin Meymun b. Muhammed. Tebsiratü'l-Edille. haz. Hüseyin Atay. Ankara: Diyanet İşleri Başkanlığı Yayınları, 2004. 


\section{MÎZÂNÜ'L-HAK \\ ISLAMI ILIMLER DERGISI}

Nursi, Bediüzzaman Said. İşaratü'l-I'caz. İstanbul: Zehra yayıncılık, 2013.

Onat, Hasan. "Özgürlük Bağlamında Din Anlayışındaki Farklılaşmalar ve Mezhepler". İlâmi Araştırmalar = Journal of Islamic Research 29/2 (2018): 169-192.

Özsöy, İsmail. “Faiz", İslam Ansiklopedisi, XII/110-126. İstanbul: TDV Yayınları, 1995.

Özler, Mevlüt. "Tevhid”, İslam Ansiklopedisi, XXXXI/18-20. İstanbul: TDV Yayınları, 2012.

Pezdevi, Ebu'l Yusr Muhammed. Usulu'd-Din (Ehl-i Sünnet Akaidi). trc. Şerafettin Gölcük. İstanbul: Kayıhan Yayınları, 1994.

Razî, Fahruddin Muhammed b. Ömer. Meâlimu Usuli'd-Din (İslam Inancının Ana Konuları. çev. Nadim Macit. Erzurum: İhtar Yayıncılık, 1996.

Sabunî, Nûreddîn. Mâturidiyye Akaidi. trc. Bekir Topaloğlu. İstanbul: M. Ü. İlahiyat Fakültesi Vakfı Yayınları, 2011.

Taftazani, Sa'duddin Mes'ud b. Ömer. Şerhu'I-Makasıd. thk. Abdurrahman Umeyre. Beyrut: Alemu'l-Kutub, 1998.

Tusî, Nasiruddin. Ahlak-ı Nasirî. çev. Anar Gafarov, Zaur Şükürov. İstanbul: Litera Yayıncılık, 2007.

Ulupınar, Hamide. Ahmet Zerrûk (Hayatı, Eserleri ve Tasavvufi Görüşleri. İstanbul: Gelenek Yayınları, 2017.

Ulupınar. "Ilk Dönem Sufilerinde Tevhid Anlayışı". Tasavvuf: IImi ve Akademik Araştırma Dergisi 22 (Temmuz-Aralık 2008): 235-255.

Ünal, Bülent. "İslam ve Siyaset Üzerine Düşünceler". DEÜiFD XIII (Kış-Ilkbahar 2001): 161-184.

Vatandaş, Celalettin. Hz. Muhammed (s.a.s.)'in Hayatı ve İslam Daveti-Mekke Dönemi. İstanbul: Pınar Yayınları, 2012.

Yavuz, Yusuf Şevki. “Kader". İslam Ansiklopedisi, XXIV/58-63. İstanbul: TDV Yayınları, 2001.

Yıldız, İbrahim. "Kur'ân-ı Kerîm'de Atalar Geleneği ve İnanca Etkisi". KSÜ Ilahiyat Fakültesi Dergisi 26 (2015): 175-215. 